\title{
Magnetic properties of surface sediments in Schirmacher Oasis, East Antarctica: spatial distribution and controlling factors
}

\author{
Anish Kumar Warrier $^{1,2}$ (D) Joju George Sebastian ${ }^{1}$ (D) K. Amrutha $^{1}$ (D) A. S. Yamuna Sali ${ }^{1}$ (D) B. S. Mahesh ${ }^{3}$ (D) \\ Rahul Mohan ${ }^{3}$ (1)
}

Received: 19 July 2020 / Accepted: 27 October 2020 / Published online: 12 November 2020

(C) The Author(s) 2020

\begin{abstract}
Purpose We investigated the magnetic properties (abundance, grain size, and mineralogy) of iron oxides present in Lake L-55 sediments, Schirmacher Oasis, East Antarctica, with an aim to understand their spatial distribution and the underlying mechanisms that control their formation and distribution.

Methods Twenty-five surficial sediments retrieved from different parts of Lake L-55 were subjected to the entire range of environmental magnetic (magnetic susceptibility, anhysteretic remanent magnetization (ARM), isothermal remanent magnetization (IRM)) measurements (at different field strengths). Inter-parametric ratios $\left(\chi_{\mathrm{ARM}} / \mathrm{SIRM}, \chi_{\mathrm{ARM}} / \chi_{\mathrm{lf}}, \chi_{\mathrm{ARM}} / \chi_{\mathrm{fd}}, \mathrm{IRM}_{20 \mathrm{mT}} /\right.$ SIRM, $\mathrm{IRM}_{20 \mathrm{mT}} / \mathrm{ARM}, S$-ratio, $L$-ratio) provided insights into the magnetic properties (abundance, grain size, and mineralogy of iron oxides). Scanning electron microscopic-energy dispersive X-ray spectroscopic (SEM-EDS) analysis was performed on magnetic extracts from a few sediments. Besides, organic matter (\%) was also calculated for the sediment samples. Principal component analysis was performed to gain information on the presence of different components and their relative dominance. Results The iron oxides are strongly magnetic (high values of concentration-dependent parameters). The principal iron oxide is magnetite ( $S$-ratio $>0.90$ ) which is coarse-grained (multi-domain $(\mathrm{MD})$ and stable single-domain (SSD) grains), and there is no influence of authigenic greigite, bacterial magnetite, and anthropogenic magnetite. The mineralogy is confirmed by SEM-EDS data. The iron oxides are of different grain sizes, and their contribution is in the order of MD > SSD > SP as shown by the principal component analysis. Pedogenic iron oxide minerals seem to be present in the samples whose formation is due to the oxidation of magnetite into hematite. However, they are of SSD size and not SP, suggesting that the intensity of pedogenesis is not sufficient to form SP grains.

Conclusion The iron oxide minerals are mainly terrigenous, and the biogenic activity within the lake is not sufficient to modify the ferrimagnetic minerals. Spatial distribution patterns suggest the non-uniform distribution of magnetite/titanomagnetite of varying sizes in the lake basin which is transported by both melt water streams and winds.
\end{abstract}

Keywords Iron oxides $\cdot$ Melt water $\cdot$ Sedimentary processes $\cdot$ Environmental magnetism $\cdot$ Aeolian $\cdot$ Weathering

We confirm that this work is original and has not been published elsewhere, nor is it currently under consideration for publication elsewhere.

Responsible Editor: Simon Pulley

Anish Kumar Warrier

akwarrier@gmail.com; anish.warrier@manipal.edu

1 Department of Civil Engineering, Manipal Institute of Technology, Manipal Academy of Higher Education, Manipal, Karnataka 576104, India
2 Centre for Climate Studies, Manipal Academy of Higher Education, Manipal, Karnataka 576104, India

3 National Centre for Polar and Ocean Research, Ministry of Earth Sciences, Headland Sada, Goa 403804 Vasco-da-Gama, India 


\section{Introduction}

Lake sediments of Antarctica and Sub-Antarctic Islands offer tremendous potential in paleoclimate/paleoenvironment studies as these sediments bear the signature of natural environmental processes as well as anthropogenic changes. A systematic study on these sediments can help us in understanding the surficial processes that are active in the lake's catchment starting from the production and transportation of detrital sedimentary particles which gets deposited in the lake basin. East Antarctica has several ice-free regions that have different types of lakes (land-locked, proglacial, and epishelf) (Ravindra 2001). The sediments in these lakes are mainly derived from the (i) weathering of catchment rocks (Warrier et al. 2016); (ii) deposition of aerosol particles (Li et al. 2010) due to volcanism (Aymerich et al. 2016); and (iii) movement of glacier over a lake (Hendy et al. 2000). Besides, organic productivity in the form of cyanobacterial mats (Smith et al. 2006) within the lake also contributes biogenic sediments to the total sediment content (Mahesh et al. 2017; Mahesh et al. 2019).

Iron oxide minerals are omnipresent in the Antarctic environment. They have been reported in soils (Chaparro et al. 2007), lake sediments (Warrier et al. 2014; Phartiyal 2014; Chaparro et al. 2014; Lecomte et al. 2016), marine mud (Sagnotti et al. 2001), and even ice cores (Lanci et al. 2012). In recent decades, environmental magnetic techniques have witnessed tremendous growth that has helped in increasing scientific knowledge of the different properties of iron oxide minerals like magnetite, hematite, titanomagnetite, and greigite. In a sedimentary environment, these minerals are extremely sensitive to subtle changes in physicochemical conditions, and these variations are best studied by characterizing the sediment magnetic properties (Liu et al. 2012; Chaparro et al. 2017). For example, iron oxide minerals can be of different grain sizes. For cubic and elongated magnetite crystals, the size can be superparamagnetic (SP; $<0.03 \mu \mathrm{m}$ ), stable single domain (SSD; $0.03-0.1 \mu \mathrm{m}$ ), pseudo single domain (PSD; 0.1-20 $\mu \mathrm{m}$ ), and multi-domain (MD; > $20 \mu \mathrm{m}$ ) (Dunlop and Ozdemir 2001; Dekkers 2007). Prior to interpreting the magnetic signal in terms of the environmental processes, it is important to ascertain the actual origin of the iron oxide minerals. The magnetism of iron oxide minerals can change due to authigenic processes that could give rise to greigite (Snowball 1991; Roberts 1995) or bacterial magnetite (Snowball 1994; Paasche et al. 2004). The ratio $\mathrm{SIRM} / \chi_{\mathrm{lf}}$ acts as an indicator for greigite with values $>30 \times$ $10^{3} \mathrm{~A} \mathrm{~m}^{-1}$ reflecting its presence in the sediments (Snowball 1991). The presence of ultrafine-grained magnetite may be indicated if the SIRM $/ \chi_{1 \mathrm{f}}$ ratio is $>40 \times 10^{3} \mathrm{~A} \mathrm{~m}^{-1}$ (Chaparro et al. 2017). Values $>200 \times 10^{-5} \mathrm{~m} \mathrm{~A}^{-1}$ for $\chi_{\mathrm{ARM}} / \mathrm{SIRM}$ (Oldfield 1994), $>40$ for $\chi_{\mathrm{ARM}} / \chi_{\mathrm{lf}}$, and $>1000$ for $\chi_{\mathrm{ARM}} / \chi_{\mathrm{fd}}$ (Oldfield 1994; Dearing 1999b) indicate the presence of bacterial magnetite. Besides, anthropogenic activities like vehicular emissions (Evans and Heller 2003), the burning of coal in power plants (Magiera et al. 2011) also contribute magnetic spherules that be deposited with the lake sediments and modify their original magnetic signal. Magnetic minerals associated with anthropogenic activities in polluted sediments are indicated by high SIRM/ $\chi_{\text {lf }}$ values (Huliselan et al. 2010; Sudarningsih et al. 2017) and are coarse-grained (PSD and MD) (Li et al. 2006; Cao et al. 2015).

Fine-grained iron oxide minerals in deposited sediments may also undergo dissolution (Anderson and Rippey 1988) under the influence of high organic content, resulting in a coarsening of the magnetic grain assemblage (Foster et al. 2008). The coarse-grained magnetic minerals arising from the catchment soils are most often well-preserved in the sediments after deposition (Liu et al. 2012). Moreover, the basic rock magnetic and inter-parametric ratios can be reliably used to get information on the source of iron oxide minerals (Walden et al. 1999). Any contributions from the aforementioned processes can be identified by distinct changes in the inter-parametric magnetic ratios. The ratios $S_{20}\left(=\mathrm{IRM}_{20 \mathrm{mT}} /\right.$ SIRM), $\chi_{\text {ARM }} / \mathrm{SIRM}, \chi_{\mathrm{ARM}} / \chi_{\mathrm{If}}$, and $\mathrm{IRM}_{20 \mathrm{mT}} / \mathrm{ARM}$ indicate the magnetic grain size. Fine grain size of magnetic minerals is indicated by larger values of the $\chi_{\mathrm{ARM}} / \mathrm{SIRM}$ and coarser magnetic grains by smaller values (Oldfield 1991). The parameters $S_{20}\left(=\mathrm{IRM}_{20 \mathrm{mT}} / \mathrm{SIRM}\right)$ and $\mathrm{IRM}_{20 \mathrm{mT}} / \mathrm{ARM}$ act as indicators of MD-sized ferrimagnetic grains. This is because $\mathrm{IRM}_{20 \mathrm{mT}}$ represents the soft component of IRM and is therefore sensitive to MD-sized ferrimagnetic grains ( $\mathrm{Lu}$ and Bai 2006). Increasing values for $S_{20}$ indicates a larger proportion of MD grains and vice versa. $\mathrm{IRM}_{20 \mathrm{mT}} / \mathrm{ARM}$ values $>50$ point towards the dominance of MD grains in the assemblage, and values $<10$ indicate larger contributions from SSD grains (Oldfield 1991). The systematic study of the type and abundance of iron oxide minerals along with its grain size has helped solve issues related to paleoclimate (Warrier et al. 2014), pollution (Chaparro et al. 2017), and pedogenesis (Sandeep et al. 2012).

Hitherto, surface sediments from different lakes in Schirmacher Oasis (SO) have been analyzed for particle size, mineralogy, the morphological features of quartz grains, and elemental geochemistry (Shrivastava et al. 2012; Srivastava et al. 2013 and references therein; Ravindra 2020). These techniques were employed to understand sediment provenance and the sedimentary processes that were taking place within the lake system and in its catchment. However, the aforementioned studies in the Schirmacher Oasis have not explored the variability in sediment magnetic properties, and there is no information on the processes related to the formation/transformation of iron oxide minerals. In this study, we present the environmental magnetic properties of the Lake L-55 sediments, a small land-locked dry lake in Schirmacher 
Oasis with an aim to (i) identify the dominant iron oxide minerals, their concentration, and grain size, and (ii) to understand the spatial distribution of these minerals and the underlying mechanisms that control their formation and distribution. The results from this study will aid scientists in the interpretation of down-core variations in environmental magnetic properties on longer sediment cores for paleoclimate studies.

\section{Materials and methods}

\subsection{Study area}

The Schirmacher Oasis (SO; Queen Maud Land, East Antarctica) covering an area of $\sim 35 \mathrm{sq}$. $\mathrm{km}$, falls between latitudes of $70^{\circ} 43^{\prime} 50^{\prime \prime}$ and $70^{\circ} 46^{\prime} 40^{\prime \prime}$ south and longitudes of $11^{\circ} 22^{\prime} 40^{\prime \prime}$ and $11^{\circ} 54^{\prime} 25^{\prime \prime}$ east. It is one of the smaller ice-free regions situated in East Antarctica (Swain 2020) and is predominantly rocky (Ravindra 2020). The SO is lying at an altitude of $\sim 100 \mathrm{~m}$ above the mean sea level between the thick continental ice sheet and the ice shelf (Fig. 1). The region is marked with hills of different elevations with an average height of $200 \mathrm{~m}$ (Srivastava and Khare 2009) with the peak of Mt. Rebristaya being the highest at $233 \mathrm{~m}$ (above mean sea level) (Swain 2020). More than 100 lakes are situated in the region, and they are characterized as epishelf, land-locked, and proglacial according to their geomorphological characteristics (Ravindra 2001). The lakes are mostly freshwater with extremely low salinity values fluctuating between 0.09 and 2.05\% (Ingole and Parulekar 1993; Khare et al. 2008). Although the region falls on the coastal part of East Antarctica, the width of the ice shelf is $\sim 100 \mathrm{~km}$, which prevents the salty marine waters from entering the region (Laybourn-Parry and Wadham 2014). The air temperature fluctuates between 0.7 and $8.2{ }^{\circ} \mathrm{C}$ during summer (December-January), and from -16.3 to $-35.5^{\circ} \mathrm{C}$ during winter with August being the coldest (Lal 2006; Mahesh et al. 2015). The southeasterly winds blow at an average speed of $9.3 \mathrm{~m} \mathrm{~s}^{-1}$ and $6.2-7.2 \mathrm{~m} \mathrm{~s}^{-1}$ in the winter and summer seasons respectively (Soni et al. 2017). Annual precipitation in the region is low with around $264.5 \mathrm{~mm}$ of snowfall (Lal 2006). The dried lake, L-55, is a landlocked (Fig. 1) small lake (0.015 sq. km) which remains dry for most part of the year and receives trickling amount of water contributed by the small melt water streams due to the thawing of snow and ice during the summer months. The geology of the catchment area is rich in metamorphosed rocks like quartzofeldspathic gneiss which are interlayered with amphibolite and mafic granulites and injected by garnet bearing leucogranite and veins of leucogneiss (Rao 2000; Bose and Sengupta 2003).

\subsection{Sampling}

Surface sediments from 25 locations (Fig. 1) in the Lake L-55 were collected during the 39th Indian Scientific Expedition to Antarctica in December 2019. On the dry lake beds, it is quite possible that the lake sedimentary surface may be subjected to deflation (Farebrother et al. 2017). Therefore, at each location, the top-most layer $(0-2 \mathrm{~cm})$ of the lake's surface was sampled. Before sampling, the coarser rock particles (fine to very fine granules) were first gently moved away using a plastic spatula. Later, a plastic scale was inserted up to a depth of $2 \mathrm{~cm}$ from the surface into each of the 25 locations. The sediments were collected using a plastic spatula and stored in two centrifuge tubes $(15 \mathrm{ml})$. On visual examination, the sediments were predominantly sandy silt in texture with little clay content. Care was taken in the field to avoid any sample contamination, and non-magnetic items of apparatus were used for sampling. On reaching the Maitri research base, the sample tubes were preserved at $\sim 4^{\circ} \mathrm{C}$.

\subsubsection{Environmental magnetic measurements}

Prior to the magnetic measurements, the sediment samples were oven-dried at $<40^{\circ} \mathrm{C}$. The samples were gently disaggregated and passed through a $2-\mathrm{mm}$ sieve to obtain the $<2-\mathrm{mm}$ size particles. Approximately $6 \mathrm{~g}$ of the $<2-\mathrm{mm}$ fractions was placed in a thin plastic film and tightly packed in pre-weighed non-magnetic plastic bottles thereby avoiding any particle movement. The sediments were subjected to environmental magnetic analysis at the CSIR-National Institute of Oceanography, Goa, India. Magnetic susceptibility values were measured at low $\left(\chi_{\mathrm{lf}}=0.47 \mathrm{kHz}\right)$ and high $\left(\chi_{\mathrm{hf}}=4.7 \mathrm{kHz}\right)$ frequencies on a Bartington MS2B dual-frequency susceptibility meter. The difference in the values of $\chi_{\mathrm{lf}}$ and $\chi_{\mathrm{hf}}$ was used to derive frequency-dependent susceptibility $\left(\chi_{\mathrm{fd}}\right)$ and its percentage $\left(\chi_{\mathrm{fd}} \%\right.$; Dearing 1999a). Anhysteretic remanent magnetization (ARM) was imparted to the samples with a $100 \mathrm{mT}$ peak alternating field superimposed with a fixed DC bias field of 50 $\mu \mathrm{T}$ on a Molspin AF demagnetizer with an ARM attachment. The ARM imparted to the samples was measured on an AGICO dual speed spinner magnetometer. The mass-specific ARM was divided by the DC bias field to estimate the susceptibility of ARM ( $\left.\chi_{\mathrm{ARM}}\right)$ (Walden et al. 1999). Isothermal remanent magnetization (IRM) was imparted to the samples in stages of incrementing field intensities $(20,40,100,300$, and $1000 \mathrm{mT}$ ) with a peak field of $1000 \mathrm{mT}$ in the forward direction, and fields of 30,100 , and $300 \mathrm{mT}$ in the backward direction using an MMPM10 pulse magnetizer. The IRM induced at $1000 \mathrm{mT}$ was considered the saturation isothermal remanent magnetization (SIRM). The IRM acquired by the samples were measured on an AGICO dual speed spinner magnetometer. After the measurements were completed, the magnetic parameters were calculated on a mass-specific basis. Inter-parametric 

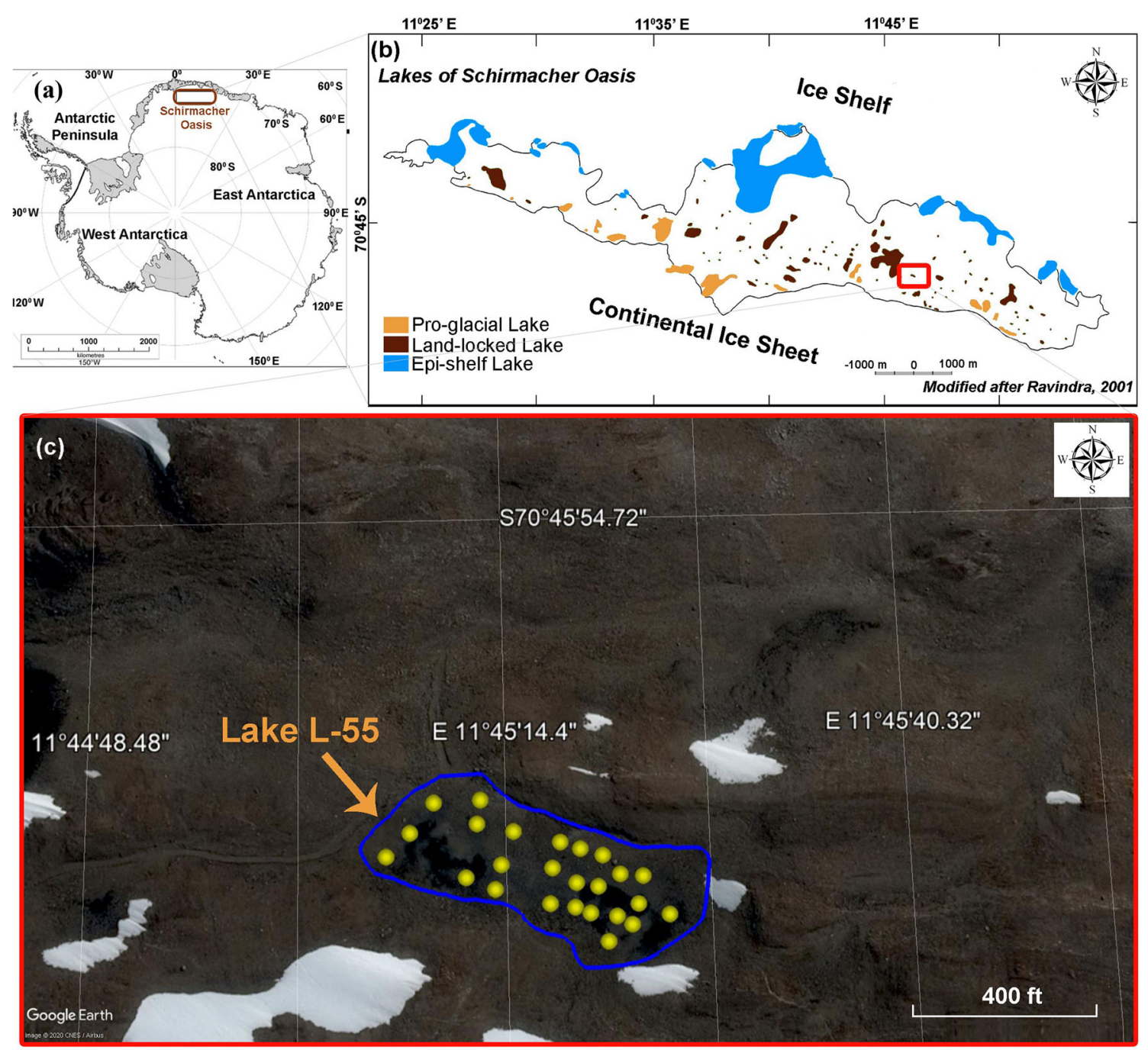

Fig. 1 (a) A general map of the Antarctic region showing the location of Schirmacher Oasis in East Antarctica; (b) a spatial distribution map of the different categories of lakes found in Schirmacher Oasis (modified after

ratios like $\chi_{\mathrm{ARM}} / \mathrm{SIRM}, \chi_{\mathrm{ARM}} / \chi_{\mathrm{If}}, \mathrm{S}_{20}\left(=\mathrm{IRM}_{20 \mathrm{mT}} / \mathrm{SIRM}\right)$, $\mathrm{IRM}_{20 \mathrm{mT}} / \mathrm{ARM}$, and SIRM/ $\chi_{\text {If }}$ were calculated from the raw data, to determine the magnetic grain size (Oldfield 1991; Walden et al. 1999). Information on the iron oxide mineralogy was obtained by calculating the following ratios: (i) $S$-ratio $\left(=\mathrm{IRM}_{-300 \mathrm{mT}} / \mathrm{SIRM}\right)$, and (ii) $L$-ratio $\left(=\left[\mathrm{SIRM}+\mathrm{IRM}_{-300}\right.\right.$ $\mathrm{mT}]$ / [SIRM + IRM $-100 \mathrm{mT}]$ ) (Liu et al. 2007; Chaparro et al. 2020a). "Hard" isothermal remanent magnetization was calculated $\left(\mathrm{HIRM}=\mathrm{SIRM}-\mathrm{IRM}_{300 \mathrm{mT}}\right.$; Walden et al. 1999) to check for the presence of hematite/goethite in the samples. The IRM acquisition curves were normalized and plotted against the applied field.

\subsubsection{SEM-EDS studies on magnetic extracts}

Iron oxide minerals were extracted from a few sediment samples of Lake L-55. To achieve this, the sample was dispersed in
Ravindra 2001), and the area surrounding the Lake L-55 (indicated by a red-colored rectangle); (c) a close view of the Lake L-55 showing the 25 sample locations from where surface sediments were collected

a $1000-\mathrm{ml}$ glass beaker containing deionized water and suspended using a magnetic stirrer. A strong neodymium magnet sealed in a zip-lock polythene cover was gently suspended in the beaker. The iron oxide minerals that stuck to the polythene cover were collected in a small beaker and dried before SEM-EDS studies (Hounslow and Maher 1999). The extracts were sputter-coated with platinum $(\sim 2$-nm thickness $)$ and examined at $\times 150$ using a JEOL-JSM-6360 LV SEM housed at the National Centre for Polar and Ocean Research, Goa. The instrument was operated at $15-20 \mathrm{keV}$. Elemental analysis of the magnetic extract was performed using an OXFORD INCA 200 energy dispersive X-ray spectrometer (EDS).

\subsubsection{Organic matter estimation}

Organic matter $(\mathrm{OM})$ content was estimated for all the 25 samples (Schumacher 2002). Approximately $3 \mathrm{~g}$ of the dried 
sediments were transferred to pre-weighed glass beakers. Fifteen milliliters of hydrogen peroxide $(30 \%)$ was added slowly into the beaker. The beakers were kept overnight to allow the reaction to complete. On the next day, the samples were washed twice with deionized water and allowed to dry on a hotplate. Once the sediments were completely dried, the weights of all the beakers were noted. The difference in the weights was used to calculate the organic matter content present in the Lake L-55 sediments.

\subsubsection{Principal component analysis}

The entire dataset pertaining to the environmental magnetic parameters and inter-parametric ratios were subjected to principal component analysis (PCA) using the PAST software (Version 4.02; Hammer et al. 2001). As the parameters and inter-parametric ratios were measured/derived in different units, we used the correlation principle (normalized varcovar) to find the eigenvalues and eigenvectors using the SVD algorithm embedded in the software. The eigenvalues provide a measure of the variance accounted for by the equivalent eigenvectors (components). The components were extracted using the varimax rotation. Furthermore, the brokenstick model (Frontier 1976) was applied to determine the important components whose eigenvalues exceeded the model (Jolliffe 2002; Olsen et al. 2012).

\section{Results}

\subsection{Magnetic concentration}

The $\chi_{\text {lf }}$ values for the Lake L-55 sediments range from 283.4 $\times 10^{-8}$ to $1339.9 \times 10^{-8} \mathrm{~m}^{3} \mathrm{~kg}^{-1}$ with an average $( \pm \mathrm{sd})$ of $627.9( \pm 217.9) \times 10^{-8} \mathrm{~m}^{3} \mathrm{~kg}^{-1}$ (Table 1$)$. The $\chi_{\mathrm{fd}} \%$ value varies between 0 and $3.16 \%$ with a mean $( \pm \mathrm{sd})$ value of $1.12 \%( \pm 0.7 \%)$ (Table 1$)$. The $\chi_{\mathrm{ARM}}$ values range from a minimum of $102.6 \times 10^{-8} \mathrm{~m}^{3} \mathrm{~kg}^{-1}$ to a maximum of 291.3 $\times 10^{-8} \mathrm{~m}^{3} \mathrm{~kg}^{-1}$ with a mean $( \pm \mathrm{sd})$ value of $193( \pm 48.5) \times$ $10^{-8} \mathrm{~m}^{3} \mathrm{~kg}^{-1}$ (Table 1). The SIRM values range from $140.5 \times$ $10^{-5}$ to $795.4 \times 10^{-5} \mathrm{~A} \mathrm{~m}^{2} \mathrm{~kg}^{-1}$. The average ( $\left.\pm \mathrm{sd}\right) \mathrm{SIRM}$ value is $522.8( \pm 180.9) \times 10^{-5} \mathrm{~A} \mathrm{~m}^{2} \mathrm{~kg}^{-1}$ (Table 1). A negative correlation is evident between $\chi_{\mathrm{lf}}$ and $\chi_{\mathrm{fd}} \%$ (Fig. 2a), and a strong relationship is evident between $\chi_{\text {If }}$ and SIRM (Table 2, Fig. 2b)

\subsection{Mineralogy of the iron oxides}

In the case of Lake L-55 sediments, the $S$-ratio values remain $>0.90$ for most of the samples with a maximum value of 0.99 indicating significant concentration of ferrimagnetic minerals such as magnetite/titanomagnetite (Table 1). However, an anomalously low $S$-ratio value of 0.77 is shown by one sample
(DLS-05), suggesting the presence of hematite in the sample. The HIRM values are low for most of the samples (mean ( \pm sd) value $=23.1( \pm 31.3) \times 10^{-5} \mathrm{~A} \mathrm{~m}^{2} \mathrm{~kg}^{-1}$ (Table 1) indicating a fairly low concentration of hematite/goethite. However, one sample (DLS-05) showing relatively high HIRM value $\left(157.40 \times 10^{-5} \mathrm{~A} \mathrm{~m}^{2} \mathrm{~kg}^{-1}\right)$ coupled with low $S$-ratio (0.77) suggests that a relatively higher concentration of hematite/ goethite may be present. The normalized IRM curves (Fig. 3a) suggest the dominance of ferrimagnetic minerals in the sediments except for the solitary sample (DLS-05) which continues to acquire remanence at greater fields. HIRM and $L$ ratio show no significant correlation (Table 2; Fig. 3b), and the $L$-ratio values remain almost constant in our samples (Table 1; Fig. 3b), due to which the $S$-ratio can be interpreted as the ratio of magnetically "soft" and "hard" minerals. The $L$-ratio here is independent of HIRM suggesting that changes in the latter are dominantly controlled by the variations in the concentration of hematite rather than the changes in the coercivity distribution of the magnetic minerals (Liu et al. 2007; Pulley et al. 2018; Chaparro et al. 2020a). Furthermore, SEM-EDS data shows that the iron oxide minerals are made up of titanomagnetite and magnetite as evident by strong peaks in $\mathrm{Fe}, \mathrm{O}$, and $\mathrm{Ti}$ (Fig. 4).

\subsection{Magnetic grain size}

The $\chi_{\text {ARM }} /$ SIRM ratio values are relatively low for most of the samples with a low of $20.74 \times 10^{-5} \mathrm{~m} \mathrm{~A}^{-1}$ and a high of 78.23 $\times 10^{-5} \mathrm{~m} \mathrm{~A}^{-1}$ and a mean $( \pm \mathrm{sd})$ value of $40.83( \pm 15.18) \times$ $10^{-5} \mathrm{~m} \mathrm{~A}^{-1}$ (Table 1). The $\chi_{\mathrm{ARM}} / \mathrm{SIRM}$ vs. $\chi_{\mathrm{fd}} \%$ biplot (Fig. 5a) gives us a fair idea about the magnetic grain size distribution (Dearing et al. 1997), and hence provides a semiquantitative assessment of the grain size of magnetic minerals and the relative contribution of SP magnetic crystals (Sandeep et al. 2012). The samples from our study are primarily in the coarse SSD region (Fig. 5a). The plots of $\chi_{\mathrm{If}}$ vs. $S_{20}$ and $\mathrm{IRM}_{20 \mathrm{mT}} / \mathrm{ARM}$ indicate a mixed assemblage of coarse SSD and MD grains (Fig. $5 b$ and c). The $\chi_{\text {ARM }}$ vs. $\chi_{\text {If }}$ biplot indicates the concentration of SSD-sized ferrimagnetic grains (Fig. 6a). Steeper slopes suggest finer SSD grains whereas gentler slopes are indicative of relatively coarser iron oxide crystals. The Lake L-55 samples plot closer to the $20-\mu \mathrm{m}$ slope line suggesting relative coarser size of the ferrimagnets. The $\chi_{\mathrm{ARM}} / \chi_{\mathrm{lf}}$ ratio varies between 0.15 and 0.60 with a mean ( \pm sd) of $0.33( \pm 0.09)$ (Table 1).

\subsection{Organic matter}

The organic matter content of the sediments is low ranging from 0.03 to $6.59 \mathrm{wt} \%$. The average ( $\pm \mathrm{sd}$ ) organic matter content is $2.78( \pm 1.93) \mathrm{wt} \%$. The organic matter data exhibits a negative to extremely weak relationship with magnetic parameters like $\chi_{\mathrm{lf}}, \chi_{\mathrm{ARM}}$, and SIRM (Table 2) suggesting the 
Table 1 Statistical summary of the environmental magnetic properties and organic matter of Lake L-55 sediments $(n=25)$.

\begin{tabular}{|c|c|c|c|c|c|c|c|}
\hline Parameters & Units & Mean & Minimum & Maximum & Std. error & Median & Std. deviation \\
\hline$\chi_{\mathrm{lf}}$ & $10^{-8} \mathrm{~m}^{3} \mathrm{~kg}^{-1}$ & 627.93 & 283.42 & 1339.97 & 43.59 & 589.10 & 217.96 \\
\hline$\chi_{\mathrm{fd}}$ & $10^{-8} \mathrm{~m}^{3} \mathrm{~kg}^{-1}$ & 6.77 & 0 & 21.84 & 0.95 & 6.63 & 4.75 \\
\hline$\chi_{\mathrm{fd}}$ & $\%$ & 1.12 & 0 & 3.16 & 0.14 & 1.22 & 0.72 \\
\hline$\chi_{\mathrm{ARM}}$ & $10^{-8} \mathrm{~m}^{3} \mathrm{~kg}^{-1}$ & 193.07 & 102.67 & 291.39 & 9.71 & 187.76 & 48.56 \\
\hline $\mathrm{IRM}_{20 \mathrm{mT}}$ & $10^{-5} \mathrm{~A} \mathrm{~m}^{2} \mathrm{~kg}^{-1}$ & 78.77 & 20.03 & 183.38 & 6.05 & 79.26 & 30.24 \\
\hline SIRM & $10^{-5} \mathrm{~A} \mathrm{~m}^{2} \mathrm{~kg}^{-1}$ & 522.82 & 140.59 & 795.45 & 36.18 & 509.41 & 180.92 \\
\hline $\mathrm{IRM}_{20 \mathrm{mT}} / \mathrm{ARM}$ & Dimensionless & 10.39 & 4.90 & 21.85 & 0.74 & 9.85 & 3.71 \\
\hline$S_{20}$ & Dimensionless & 0.15 & 0.09 & 0.23 & 0.01 & 0.15 & 0.03 \\
\hline$\chi_{\mathrm{ARM}} / \mathrm{SIRM}$ & $10^{-5} \mathrm{~m} \mathrm{~A}^{-1}$ & 40.83 & 20.74 & 78.23 & 3.04 & 35.33 & 15.18 \\
\hline$\chi_{\mathrm{ARM}} / \chi_{\mathrm{If}}$ & Dimensionless & 0.33 & 0.15 & 0.60 & 0.01 & 0.31 & 0.09 \\
\hline$\chi_{\mathrm{ARM}} / \chi_{\mathrm{fd}}$ & Dimensionless & 57.13 & 9.66 & 359.91 & 16.30 & 29.73 & 79.87 \\
\hline $\mathrm{SIRM} / \chi_{\mathrm{lf}}$ & $10^{3} \mathrm{~A} \mathrm{~m}^{-1}$ & 0.86 & 0.50 & 1.32 & 0.05 & 0.77 & 0.27 \\
\hline$S$-ratio & Dimensionless & - & 0.77 & 0.99 & - & - & - \\
\hline HIRM & $10^{-5} \mathrm{~A} \mathrm{~m}^{2} \mathrm{~kg}^{-1}$ & 23.09 & 2.37 & 157.40 & 6.27 & 11.69 & 31.36 \\
\hline$L$-ratio & Dimensionless & - & 1.16 & 1.34 & - & - & - \\
\hline Organic matter & $\mathrm{Wt} \%$ & 2.78 & 0.03 & 6.59 & 0.39 & 2.81 & 1.94 \\
\hline
\end{tabular}

dilution of the magnetic signal as organic matter is diamagnetic (Walden et al. 1999).

\subsection{Results of the principal component analysis}

In this study, five components were found to have eigenvalues $>1$. However, on applying the broken-stick model (Frontier 1976), only four components were significant as their eigenvalues crossed the broken-stick line. Table 3 summarizes the loading values of the parameters on the four components, which accounts for $88.78 \%$ of variance in the entire dataset. The first principal component explains $45.6 \%$ of the total variance in the data (Table 3). Values of all the remanence parameters and $\chi_{\mathrm{lf}}$ are significantly correlated with $\mathrm{PC} 1$
(Table 3). The second (16.9\%), third (13.74\%), and the fourth (12.38\%) principal components account for the remaining variance in the data. The PC2 component is significantly correlated with the $\mathrm{IRM}_{20 \mathrm{mT}} / \mathrm{SIRM}\left(S_{20}\right)$ ratio, followed by $\chi_{1 \mathrm{f}}$, $\chi_{\mathrm{fd}}$, and $\mathrm{IRM}_{20 \mathrm{mT}} / \mathrm{ARM}$. The PC3 component is controlled mainly by $\chi_{\mathrm{ARM}}$ followed by the inter-parametric ratios associated with it (Table 3). The fourth component (PC4) shows an affinity to $\chi_{\mathrm{fd}} \%$, and $\chi_{\mathrm{fd}}$ followed by HIRM.

\subsection{Spatial variability of the magnetic properties and organic matter}

Figure 7 illustrates the spatial distribution of magnetic parameters and inter-parametric ratios highlighting the
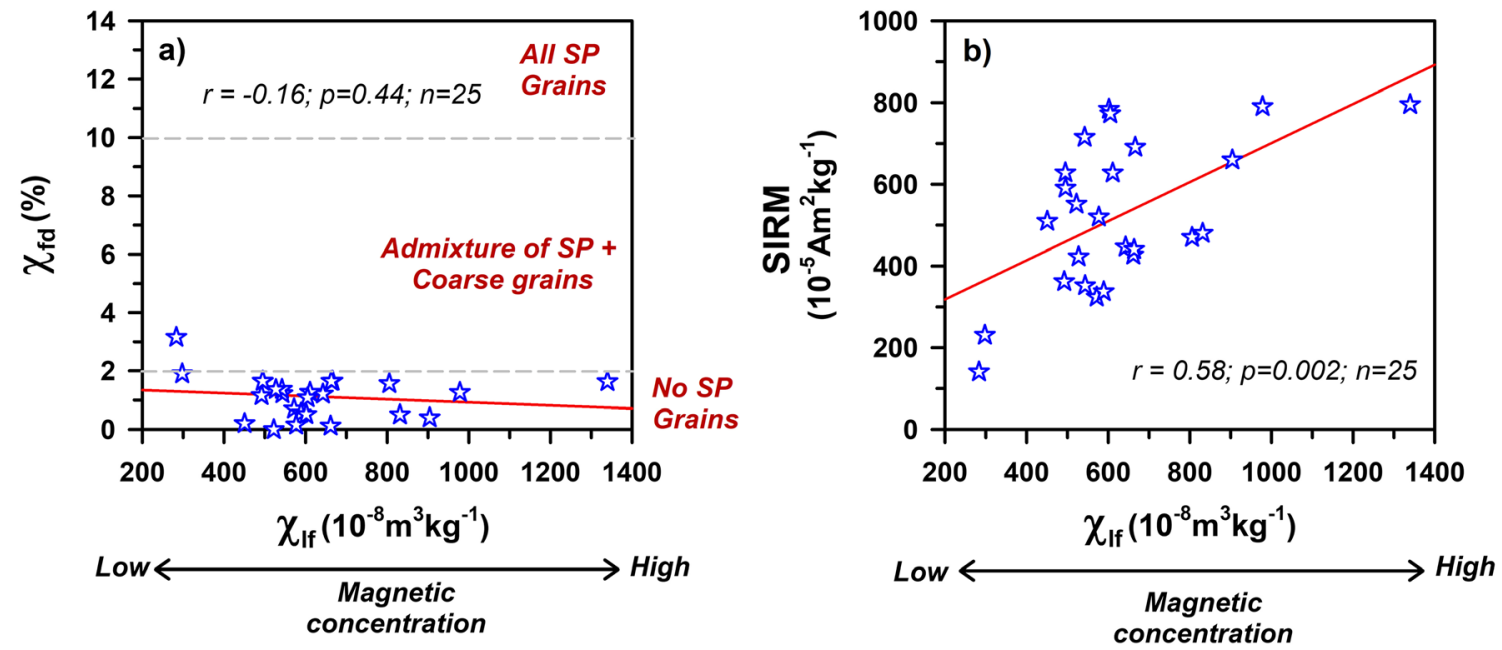

Fig. 2 Scatter plots of (a) $\chi_{\mathrm{fd}} \%$ vs. $\chi_{\mathrm{lf}}$ showing that a large proportion of the magnetic minerals in the L-55 sediments are not of SP-size; and (b) $\chi_{\mathrm{lf}}$ vs. SIRM exhibiting a good positive relationship suggesting a large proportion of ferrimagnetic minerals 
Table 2 Pearson correlation coefficient matrix for the environmental magnetic and organic matter data of the Lake L-55 sediments $(n=25)$

\begin{tabular}{|c|c|c|c|c|c|c|c|c|c|c|c|c|c|c|c|}
\hline & $\sum_{0}^{0}$ & $\Sigma$ & $\frac{\bar{z}}{3}$ & 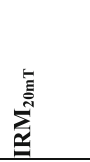 &  & $\sqrt{2}$ &  & 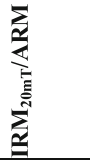 & हิ & 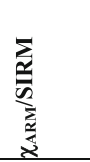 & 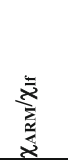 & $\frac{\sqrt[3]{2}}{\frac{\pi}{2}}$ & $\sum_{\bar{x}}^{\frac{u}{z}}$ & 竧 & 兽 \\
\hline & & & & & & & & & & & & & & & \\
\hline$\chi_{\text {If }}$ & -0.10 & & & & & & & & & & & & & & \\
\hline$\chi_{\text {ARM }}$ & 0.02 & $0.46^{*}$ & & & & & & & & & & & & & \\
\hline IRM $_{20 \mathrm{mT}}$ & -0.07 & $0.86^{* *}$ & $0.46^{*}$ & & & & & & & & & & & & \\
\hline SIRM & 0.05 & $0.58 * *$ & $0.46^{*}$ & $0.74 * *$ & & & & & & & & & & & \\
\hline$\chi_{\mathrm{fd}}$ & 0.21 & $0.57^{* *}$ & 0.16 & $0.53^{* *}$ & 0.29 & & & & & & & & & & \\
\hline$\chi_{\mathrm{fd}} \%$ & 0.34 & -0.16 & -0.17 & -0.15 & -0.22 & $0.67 * *$ & & & & & & & & & \\
\hline $\mathrm{IRM}_{20 \mathrm{mT}} / \mathrm{ARM}$ & -0.18 & $0.59 * *$ & -0.15 & $0.78^{* *}$ & $0.51^{* *}$ & 0.34 & -0.20 & & & & & & & & \\
\hline$S_{20}$ & -0.25 & $0.40^{*}$ & 0.08 & $0.40^{*}$ & -0.30 & 0.25 & -0.01 & 0.39 & & & & & & & \\
\hline$\chi_{\text {ARM }} /$ SIRM & 0.03 & -0.37 & 0.10 & $-0.52 * *$ & $-0.77^{* *}$ & -0.13 & 0.32 & $-0.68^{* *}$ & 0.31 & & & & & & \\
\hline$\chi_{\mathrm{ARM}} / \chi_{\mathrm{If}}$ & 0.17 & $-0.61^{* *}$ & 0.30 & $-0.45^{*}$ & -0.27 & -0.26 & 0.21 & $-0.70^{* *}$ & -0.26 & $0.59 * *$ & & & & & \\
\hline$\chi_{\mathrm{ARM}} / \chi_{\mathrm{fd}}$ & -0.16 & -0.07 & 0.32 & -0.09 & -0.08 & $-0.58^{* *}$ & $-0.63^{* *}$ & -0.24 & 0.01 & 0.23 & 0.25 & & & & \\
\hline SIRM $/ \chi_{\text {If }}$ & 0.07 & -0.26 & 0.08 & 0.09 & $0.62^{* *}$ & -0.19 & -0.14 & 0.10 & $-0.69^{* *}$ & $-0.58^{* *}$ & 0.26 & -0.01 & & & \\
\hline S-ratio & -0.34 & -0.16 & -0.28 & -0.33 & $-0.44^{*}$ & -0.35 & -0.24 & -0.13 & 0.15 & 0.23 & -0.06 & 0.17 & -0.31 & & \\
\hline HIRM & 0.31 & 0.26 & 0.33 & $0.44^{*}$ & $0.56^{* *}$ & 0.37 & 0.17 & 0.22 & -0.15 & -0.34 & -0.01 & -0.17 & 0.37 & $-0.99 * *$ & \\
\hline L-ratio & 0.33 & -0.38 & -0.07 & $-0.45^{*}$ & -0.36 & -0.35 & -0.11 & $-0.49^{*}$ & -0.26 & 0.33 & $0.40^{*}$ & 0.29 & -0.02 & 0.15 & -0.19 \\
\hline
\end{tabular}

Significance values $(p)^{*} \leq 0.05 ; * * \leq 0.01$

concentration, mineralogy, and grain size of iron oxide minerals present in the Lake L-55 sedimentary basin. The western and eastern flanks of the lake register the highest values of $\chi_{\mathrm{lf}}$ indicating a greater abundance of iron oxide minerals. These iron oxides are mainly coarse-grained ferrimagnets as indicated by lower values of $\chi_{\mathrm{ARM}} / \mathrm{SIRM}$ and fairly high values of $S$ ratio. Mimicking the $\chi_{\text {If }}$ distribution, SIRM values also show higher values on the eastern flank indicating a higher concentration of ferrimagnetic minerals. The $\chi_{\mathrm{fd}} \%$ registers higher values $(3.16 \%)$ in the southwestern region suggesting a relatively higher proportion of fine-grained magnetic minerals, which is also complemented by high $\chi_{\mathrm{ARM}} / \mathrm{SIRM}$ values. The eastern flank has a higher concentration of coarsegrained ferrimagnetic minerals as seen by the high values of SIRM and low values of $\chi_{\text {ARM }} /$ SIRM (Fig. 7f). These coarse grains are possibly a mixture of SSD and MD grains. A higher organic matter content is mainly observed in the western part of the lake. The northern and the eastern parts of the lake show relatively lower level of organic matter (Fig. 7i).

\section{Discussion}

\subsection{Origin of iron oxide minerals in surface sediments of Lake L-55 and their properties}

Lacustrine sediments primarily contain catchment-derived detrital sediments (including iron oxide minerals). The sedimentary sequence also contains organic matter which may be derived from within the lake (cyanobacterial mats: autochthonous) or from the catchment area (mosses/lichens: allochthonous). However, before interpreting the magnetics data, it is imperative to ascertain the origin of iron oxide minerals (see the "Introduction" section for the different sources of iron oxides). The mean values (Table 1$)$ of ratios $\left(\chi_{\mathrm{ARM}} /\right.$ SIRM, $\chi_{\mathrm{ARM}} / \chi_{\mathrm{lf}}$, and $\chi_{\mathrm{ARM}} / \chi_{\mathrm{fd}}$; Oldfield 1994; Dearing 1999b) are well below the threshold limits for bacterial magnetite, hence, ruling out any contribution from bacterial magnetite. The values of the ratio SIRM $/ \chi_{\mathrm{lf}}$ are significantly lower than the values representing greigite, suggesting its absence in the lake L-55 sediments (Table 1). The samples from our study plot primarily in the coarse SSD region (Fig. 6a), thus ruling out the presence of significant amounts of anthropogenic magnetic particles. Furthermore, the maximum SIRM $/ \chi_{\mathrm{If}}$ value obtained in our study is $1.32 \times 10^{3} \mathrm{~A} \mathrm{~m}^{-1}$ (Table 1). From the above data, it is clear that there are neither significant inputs from bacterial magnetite or anthropogenic minerals in the magnetic signal nor is it affected by the formation of authigenic greigite. In addition, no indication of dissolution diagenesis processes was observed. Besides, the organic content in the Lake L-55 sediments is extremely low (Table 1) suggesting low primary productivity in the lake and therefore reduced potential for diagenetic processes to modify the original magnetic signal of the sediments. Hence, it is confirmed that the iron oxide minerals present in the surface sediments of Lake L-55 are principally catchment-derived.

Magnetic susceptibility is the degree of the magnetizability of a sample (Walden et al. 1999; Evans and Heller 2003). It gives us information on the total concentration of the iron oxide minerals present in natural materials. In this study, the 



Fig. 3 (a) Normalized IRM curves against the applied magnetic field for the Lake L-55 sediments, and (b) scatter plot of $L$-ratio vs. HIRM. The red lines denote $95 \%$ confidence interval

high $\chi_{\mathrm{lf}}$ values observed in our samples suggest the presence of strongly ferrimagnetic minerals (Table 1 ). The parameter $\chi_{\mathrm{fd}}$ indicates the degree of pedogenesis, whereas $\chi_{\mathrm{fd}} \%$ provides hints on the occurrence of ultrafine superparamagnetic (SP) grains in the sediments (Walden et al. 1999; Evans and Heller 2003). High $\chi_{\mathrm{fd}} \%$ values $>10$ suggest significant concentrations $(>75 \%)$ of superparamagnetic grains in the sediments (Dearing et al. 1997), whereas low $\chi_{\mathrm{fd}} \%$ values $<2 \%$ indicate the absence of SP grains (Dearing 1999b). The mean $\chi_{\mathrm{fd}} \%$ value for this study is $1.12 \%$ (Table 1 ) indicating a negligible proportion of SP grains in the Lake L-55 sediments. The scatter plot (Fig. 2a) between $\chi_{\mathrm{lf}}$ and $\chi_{\mathrm{fd}} \%$ shows that most of the samples possess $\chi_{\mathrm{fd}} \%$ values $<2 \%$ and lie in the region of "no SP grains" again suggesting little contribution from SP grains to the magnetic properties of the surface sediments of Lake L-55. The parameter $\chi_{\text {ARM }}$ shows acute sensitivity to stable single-domain (SSD) grains in the sediments (Maher 1988). A strong correlation is exhibited between $\chi_{\text {ARM }}$ and $\chi_{\text {lf }}$ (Table 2 ) suggesting the dominant control of
SSD grains on sediment magnetic susceptibility signal. The SIRM acts as an indicator of all the remanence-carrying iron oxide minerals (Walden et al. 1999). SIRM values remain relatively high for most of the samples signifying the dominance of ferrimagnetic minerals in the samples. A statistically strong positive relationship is also evident between $\chi_{\mathrm{lf}}$ and SIRM ( $r=0.58, p=0.002 ; n=25$; Fig. $2 b)$ suggesting that the magnetic signal of the surface sediments of Lake L-55 is dominated by magnetically strong ferrimagnetic minerals.

The ratios $S_{20}\left(\mathrm{IRM}_{20 \mathrm{mT}} / \mathrm{SIRM}\right), \chi_{\mathrm{ARM}} / \mathrm{SIRM}$, and $\mathrm{IRM}_{20}$ $\mathrm{mT} / \mathrm{ARM}$ indicate magnetic grain size. Fine grain size of magnetic minerals is indicated by larger values of the $\chi_{\text {ARM }} / \mathrm{SIRM}$ and coarser magnetic grains by smaller values (Oldfield 1991). The ratio $\chi_{\mathrm{ARM}} / \chi_{\mathrm{lf}}$ is also a grain size-dependent parameter exhibiting similar properties to that of $\chi_{\mathrm{ARM}} / \mathrm{SIRM}$ (Oldfield 1991). Significant correlation observed between $\chi_{\mathrm{ARM}} / \mathrm{SIRM}$ and $\chi_{\mathrm{ARM}} / \chi_{\mathrm{If}}(r=0.59, p=0.002, n=25$; Table 2), combined with the low $\chi_{\mathrm{ARM}} / \mathrm{SIRM}$ values and extremely low SIRM/ $\chi_{\text {lf }}$ values, suggests the dominance of coarse-grained magnetic minerals. The parameters $S_{20}$ and $\chi_{\text {ARM }}$ have positive correlation with $\chi_{\text {If }}$ (Table 2), suggesting that both SSD- and MD-sized grains contribute towards the magnetic concentration in the surface sediments of Lake L-55. Furthermore, $\mathrm{IRM}_{20 \mathrm{mT}}$ is also used to identify the presence of soft components (principally MD grains) in the environmental samples (Xie et al. 1999). The $\mathrm{IRM}_{20 \mathrm{mT}}$ exhibits extremely strong correlations with $\chi_{\mathrm{lf}}$ and SIRM (Table 2) suggesting that with an increase in the proportion of the MD grains, the susceptibility and remanent values also rise. A strong correlation is seen between $\mathrm{IRM}_{20 \mathrm{mT}} / \mathrm{ARM}$ and $\chi_{\mathrm{lf}}(r=0.59, p=$ $0.002 ; n=25$; Fig. 5 c) suggesting that the SSD grains also have a bearing on the magnetic signal apart from the MD grains. The $\chi_{\mathrm{ARM}}$ vs. $\chi_{\mathrm{If}}$ biplot (Fig. 6a, King et al. 1982) provides semi-quantitative information on the grain size. The Lake L-55 data was plotted along with that of Lake Anónima, Vega Island, Antarctic Peninsula (Chaparro et al. 2017), and Lake Sandy, Schirmacher Oasis (Warrier et al. 2014). The data for the Lake L-55 sediments suggest that the size of the grains lie close to $20 \mu \mathrm{m}$ and that of Lake Anónima is $<0.1 \mu \mathrm{m}$, whereas samples of Lake Sandy plot between 0.2 and $<20 \mu \mathrm{m}$. According to Peters and Dekkers (2003), the $\chi_{\mathrm{ARM}} / \chi_{\mathrm{lf}}$ ratio values $>5$ suggest the presence of finer magnetite crystals. The mean $( \pm \mathrm{sd})$ value of this ratio for the Lake L-55 sediments is considerably less than $5(0.33( \pm 0.09)$; Table 1), indicating the presence of coarse-grained (MD and SSD) magnetite/titanomagnetite crystals. In comparison, the magnetic minerals found in the sediments of Lake Anónima (Chaparro et al. 2017) are much finer than that of Lake L-55 sediments (Fig. 6b). This difference is mainly due to the relatively higher temperatures experienced in the Antarctic Peninsula during the recent decades leading to stronger pedogenesis which may result in the transformation of primary iron oxide minerals into secondary ones with a significant 
(a)

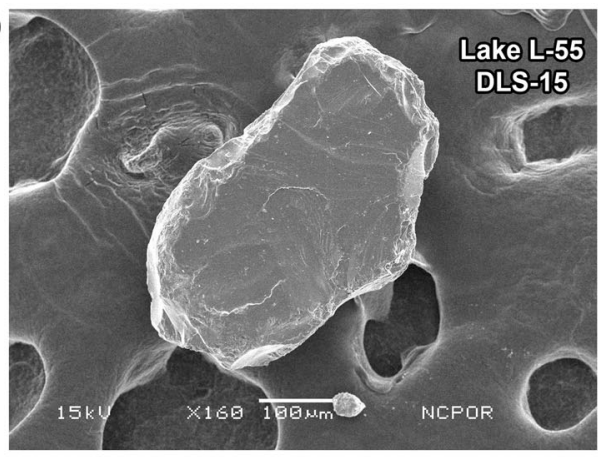

(c)

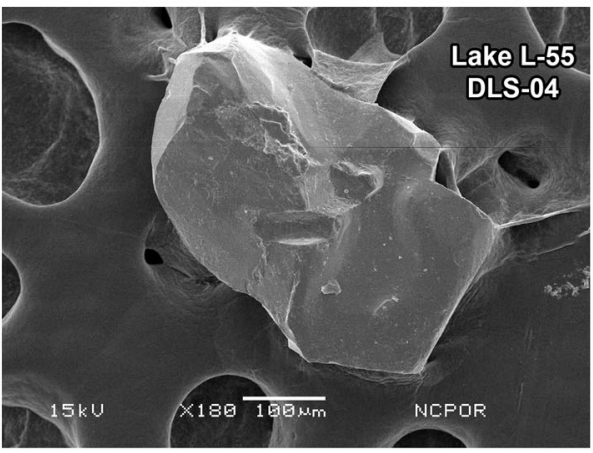

(b)

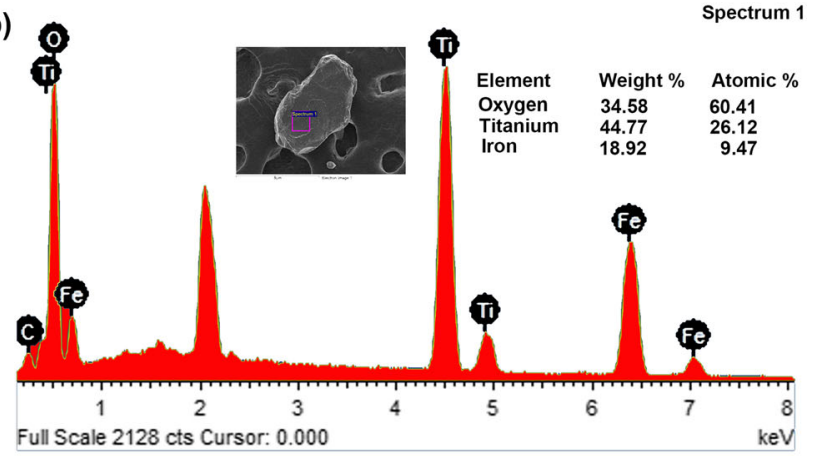

(d)



Fig. 4 Scanning electron microscopic and energy dispersive X-ray spectroscopic (SEM-EDS) data for magnetic extracts from two samples, i.e., DLS-15 and DLS-04

reduction in the magnetic grain size (SP and fine SSD). The widespread behavior in terms of the magnetic grain size seen in the case of Lake Sandy (PSD and MD, Fig. 6b) sediments may be due to post-depositional diagenesis that would have caused partial modification of the magnetic grain size.

The $S$-ratio values of the Lake L-55 sediments is $>0.90$ (Table 1) suggesting the presence of softer ferrimagnets like magnetite/titanomagnetite (Evans and Heller 2003). The HIRM values (Table 1) are quite low indicating very small proportion of canted antiferromagnets like hematite/goethite in these sediments. Normalized IRM curves also corroborate the presence of magnetite/titanomagnetite (Fig. 3a). However, more conclusive evidence is needed to characterize the iron oxide minerals. This could potentially be obtained by using semi-quantitative methods like Mössbauer spectroscopy, diffuse reflectance spectroscopy, and low-temperature magnetic measurements (Liu et al. 2007). As such measurements are beyond the scope of this investigation, instead, we relied on the simple rock magnetic parameters and inter-parametric ratios to determine the iron oxide mineralogy of Lake L-55 sediments with corroboration from SEM-EDS studies. The SEM-EDS data of magnetic extracts from these sediments reveal the presence of coarse-grained magnetite and titanomagnetite as the principal carriers of magnetic remanence (Fig. 4). Small amounts of terrigenous elements like $\mathrm{Al}$ and $\mathrm{Si}$ are also present (Fig. 4d). The association of these detrital elements with $\mathrm{Fe}, \mathrm{O}$, and $\mathrm{Ti}$ suggests that the iron oxide minerals present in the Lake L-55 sediments are landderived (Williamson et al. 1998). Furthermore, a higher amount of organic productivity within the lake system would likely dilute the magnetic signal and also lead to authigenesis leading to the production of greigite. In the lake L-55 samples, greigite is absent as evident by the extremely low SIRM/ $\chi_{\text {If }}$ ratio (Table 1). Besides, organic matter in the sediments is also low (2.78 ( \pm 1.94$) \mathrm{wt} \%$, Table 1). The negative relationship between OM and magnetic parameters suggests that the ferrimagnetic minerals present in the Lake L-55 sediments are mainly terrigenous and with no major contribution from any sort of biological action. Previous rock magnetic studies from Schirmacher Oasis have also identified the presence of magnetite and titanomagnetite (Phartiyal 2014; Warrier et al. 2014). The major source of these ferrimagnets is the gneissic rocks of the Pre-Cambrian crystalline basement of the Schirmacher Oasis (Phartiyal 2014).

\subsection{Principal component analysis of the environmental magnetic data}

The general variance in a multi-proxy database containing large amounts of variables and datasets can be observed by converting them into smaller variables using statistical procedures such as principal component analysis (Harper 1999). Based on the results of PCA, the PC1 is designated as the "magnetic concentration" component. As $S_{20}$ is a proxy for 

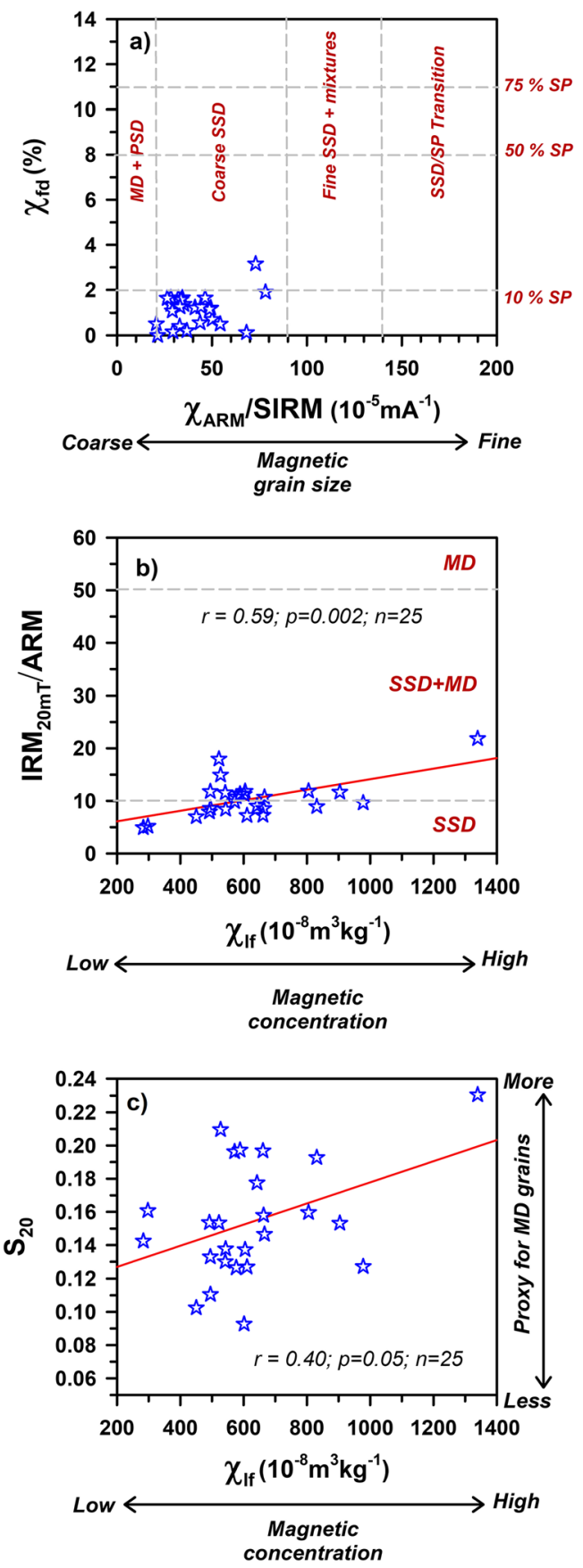

Fig. 5 Bivariate plots of (a) $\chi_{\mathrm{fd}} \%$ vs. $\chi_{\mathrm{ARM}} / \mathrm{SIRM}$ demonstrating that the iron oxide minerals in the Lake L-55 sediments belong to the coarse SSD and partly MD + PSD grain size with $<10 \%$ contribution from SP grains, (b) $\mathrm{IRM}_{20 \mathrm{mT}} / \mathrm{ARM}$ vs. $\chi_{\mathrm{lf}}$ indicating the control of SSD grains on the magnetic susceptibility signal, and (c) $S_{20}$ vs. $\chi_{\text {lf }}$ showing the presence of MD grains in various proportions

coarse magnetic crystals such as multi-domain (MD) grains (Oldfield 1991), the PC2 component is termed as the "MD grains" component. PC3 is termed as the "SSD grain" component because of the sensitivity of the parameter $\chi_{\text {ARM }}$ to the stable single-domain (SSD) iron oxide crystals (Evans and Heller 2003). The $\chi_{\mathrm{fd}}$ parameter indicates the concentration of pedogenic magnetic minerals, and $\chi_{\mathrm{fd}} \%$ indicates the concentration of SP grains present in the samples (Dearing 1999a). Besides, HIRM is suggestive of the total concentration of hematite/goethite (Walden et al. 1999). Therefore, PC4 is classified as the "pedogenic hematite" that is formed in the soils/sediments of the Lake L-55 catchment. Even though the concentration of hematite in the Lake L-55 sediments is extremely low (Table 1), the pedogenic content may be derived due to the oxidative transformation of magnetite to hematite (Chen et al. 2010). Maher (1988) deduced that an enhanced dry season along with favorable oxidizing conditions results in the rapid oxidation of fine-grained magnetite to maghemite and then to hematite. However, more studies such as DRS and inorganic geochemistry need to be done to ascertain the presence of hematite in these sediments. The PC1 vs. PC2 biplot (both accounting for a majority of the variance, $\sim 62.66 \%$; Table 3) (Supplementary Figure S1) illustrates the association between all the parameters. The length of the vector associated with each parameter and inter-parametric ratios indicates the overall strength of that variable on components 1 and 2, and the location in ordination space illustrates the direction of influence. For example, $\chi_{\mathrm{ARM}} / \chi_{\mathrm{If}}$ and $\mathrm{SIRM} / \chi_{\mathrm{lf}}$ are related to low and high values on component 1 , and $\mathrm{IRM}_{20 \mathrm{mT}} /$ SIRM is associated with high values on component 2 . Based on the PCA, it can be understood that the magnetic concentration (PC1) is largely controlled by the presence of ferrimagnetic grains like magnetite/titanomagnetite (Supplementary Figure S1). The grain size of these ferrimagnets varies with multi-domain grains being the dominant (PC2) followed by SSD grains (PC3). In addition, pedogenesis in the lake's catchment is also evident with the occurrence of hematite (PC4) formed due to the pedogenic transformation of primary magnetic minerals in the L-55 Lake's catchment. However, the intensity of pedogenesis is not strong in the catchment as evident by higher concentration of coarse-grained iron oxide minerals, which is corroborated by the dominant variances exhibited by the PC2 and PC3 components.

\subsection{Is pedogenesis occurring in the Lake L-55 catchment?}

Pedogenesis occurs under relatively warm climatic conditions. The iron present in non-magnetic iron oxide minerals is released as $\mathrm{Fe}^{2+}$ ions. These ions, under suitable Eh-pH conditions, are converted into magnetite (Maher and Taylor 1988; Maher 2009). Such secondary, pedogenic magnetite is strongly magnetic and ultrafine (SP or SSD). As there is no permanent ice cover in the catchment of the Lake L-55, the snow that it receives during the winter precipitation gets thawed during the summer, supporting soil formation. The parameter $\chi_{\mathrm{fd}}$ is an indicator of pedogenic iron oxide minerals formed during soil formation (Evans and Heller 2003), and $\chi_{\mathrm{fd}} \%$ denotes the proportion of the superparamagnetic grains. 
Fig. 6 Estimates of the magnetic grain size using (a) $\chi_{\text {ARM }}$ Vs. $\chi_{\text {lf }}$ data (calibration lines representing the different size fractions are drawn from King et al. 1982); (b) $\chi_{\mathrm{ARM}} / \chi_{\mathrm{If}}$ data for Lake L-55 sediments, Lake Anónima, Vega Island, Antarctic Peninsula (Chaparro et al. 2017) and Lake Sandy, Schirmacher Oasis, East Antarctica (Warrier et al. 2014). The size envelopes are from Chaparro et al. (2020b); and (c) biplot of $S_{20}$ vs. $\chi_{\text {ARM }} /$ SIRM comparing the grain size of the iron oxide minerals present in the Lake L-55 sediments with that of synthetic magnetite crystals (Dankers 1978; Maher 1988). The values for the synthetic magnetite crystals are in microns
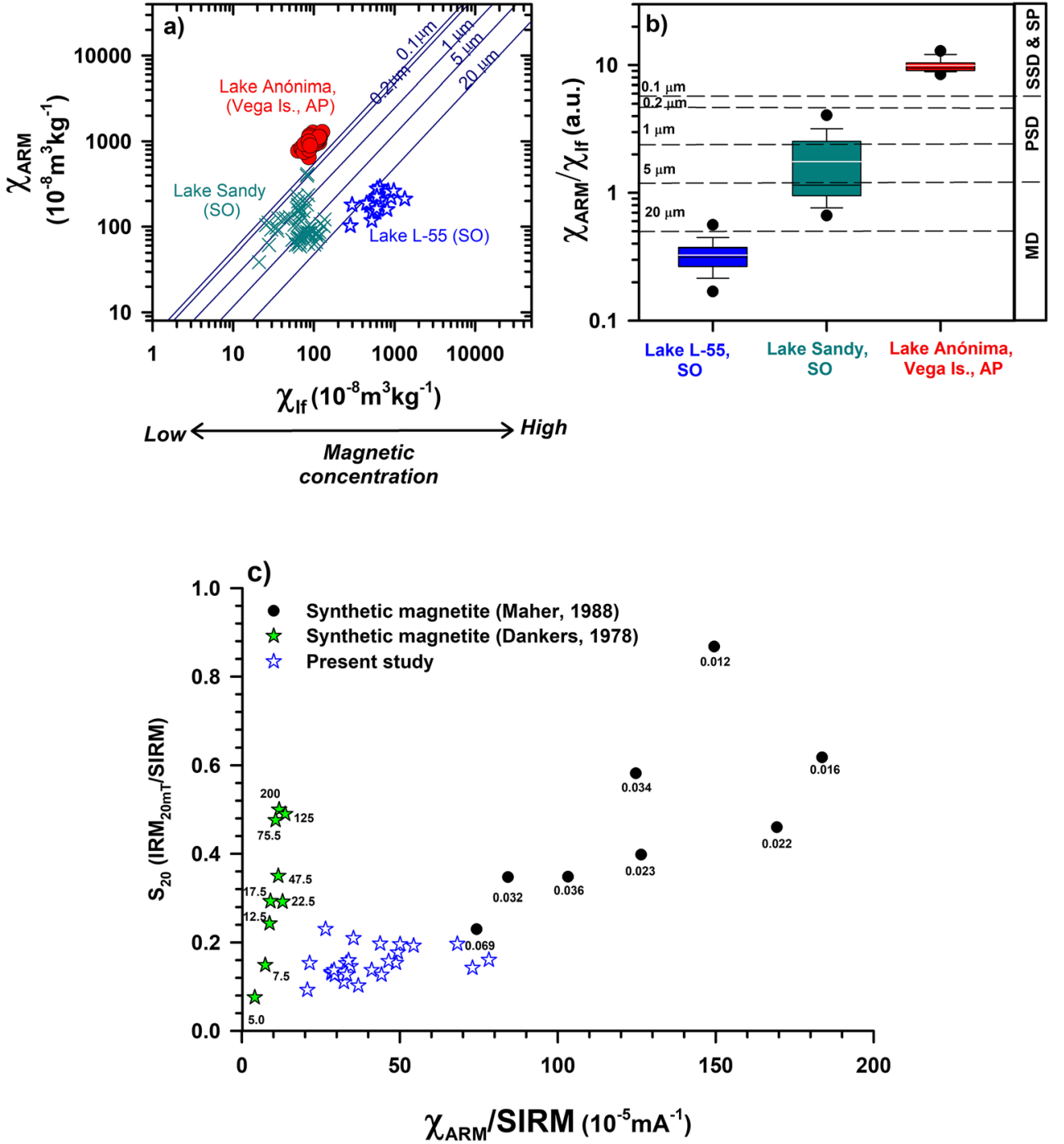

Statistically significant correlations are seen between $\chi_{\mathrm{lf}}$ and $\chi_{\underline{\mathrm{fd}}}(r=0.57 ; p=0.003 ; n=25)$ and between $\chi_{\underline{\mathrm{fd}}}$ and $\chi_{\underline{\mathrm{fd}}} \%(r$ $=0.67, p=0.0002 ; n=25)$. This suggests that pedogenesis may be occurring in the Lake L-55 catchment. Surprisingly, a negative relationship is evident between $\chi_{\mathrm{fd}} \%$ and $\chi_{\mathrm{lf}}$ (Fig. 2a, Table 2) indicating that the $\chi_{\text {lf }}$ signal is mainly controlled by the MD- and SSD-sized ferrimagnets. It may also be possible that the intensity of pedogenesis is not sufficient to favor the production of ultrafine-grained superparamagnetic grains, which is substantiated by the low $\chi_{\mathrm{fd}} \%$ values (Table 1 ). This is supported further by the $S_{20}$ vs. $\chi_{\mathrm{ARM}} / \mathrm{SIRM}$ biplot (Fig. 6c) which shows a clear distinction of the magnetic grain size. High $\chi_{\mathrm{ARM}} / \mathrm{SIRM}$ values are indicative of fine-grained particles and vice versa. Increased (decreased) $S_{20}$ values indicate more (less) multi-domain (MD) magnetic minerals. In this biplot, the Lake L-55 magnetic grain size data is plotted along with that of synthetic magnetite crystals reported by Dankers (1978) and Maher (1988). The Lake L-55 samples plot in the lower-left section of the plot suggesting that the magnetic minerals are sized between 0.069 and 7.5 microns (Fig. 6c) and may have been mainly derived from the catchment.

\subsection{Spatial variability of iron oxide minerals in the Lake L-55 basin}

To effectively reconstruct the paleoclimate/paleoenvironment, it is important to understand the spatial distribution of biogenic and abiogenic sediments in depositional basins (Avinash et al. 2016; Guan et al. 2019). Overall, the distribution of MD, SSD, and SP grains in the Lake L-55 shows different patterns reflecting a change in the surface runoff processes and a possible re-distribution of the sediments in the basin due to the accumulation and melting of snow. The intensity of the melt water streams is high during the austral summer due to relatively warmer air temperatures (Warrier et al. 2016). As the water flows through the catchment, it will pick up 
Table 3 Principal component loadings on magnetic parameters for Lake L-55 sediments

\begin{tabular}{|c|c|c|c|c|}
\hline Loadings on & $\mathrm{PC} 1$ & $\mathrm{PC} 2$ & $\mathrm{PC} 3$ & $\mathrm{PC} 4$ \\
\hline$\chi_{\mathrm{lf}}$ & 0.78 & 0.52 & 0.21 & -0.07 \\
\hline$\chi_{\text {ARM }}$ & 0.49 & -0.17 & 0.83 & 0.04 \\
\hline $\mathrm{IRM}_{20 \mathrm{mT}}$ & 0.90 & 0.31 & 0.10 & -0.01 \\
\hline $\mathrm{IRM}_{40 \mathrm{mT}}$ & 0.98 & 0.08 & 0.05 & -0.03 \\
\hline $\mathrm{IRM}_{100 \mathrm{mT}}$ & 0.97 & -0.18 & -0.02 & -0.04 \\
\hline $\mathrm{IRM}_{300 \mathrm{mT}}$ & 0.92 & -0.28 & -0.08 & -0.14 \\
\hline $\mathrm{IRM}_{500 \mathrm{mT}}$ & 0.93 & -0.33 & -0.07 & -0.04 \\
\hline SIRM & 0.94 & -0.30 & -0.07 & -0.04 \\
\hline$\chi_{\mathrm{fd}}$ & 0.57 & 0.45 & -0.03 & 0.67 \\
\hline$\chi_{\mathrm{fd}} \%$ & -0.18 & 0.14 & -0.12 & 0.88 \\
\hline $\mathrm{IRM}_{20 \mathrm{mT}} / \mathrm{ARM}$ & 0.66 & 0.41 & -0.44 & -0.18 \\
\hline$S_{20}$ & -0.001 & 0.82 & 0.28 & -0.04 \\
\hline$\chi_{\mathrm{ARM}} / \mathrm{SIRM}$ & -0.72 & 0.18 & 0.58 & 0.23 \\
\hline$\chi_{\mathrm{ARM}} / \chi_{\mathrm{lf}}$ & -0.43 & -0.57 & 0.48 & 0.27 \\
\hline$\chi_{\mathrm{ARM}} / \chi_{\mathrm{fd}}$ & -0.12 & -0.22 & 0.52 & -0.59 \\
\hline $\mathrm{SIRM} / \chi_{\mathrm{lf}}$ & 0.36 & -0.83 & -0.29 & -0.02 \\
\hline$S$-ratio & -0.45 & 0.28 & -0.04 & -0.61 \\
\hline HIRM & 0.57 & -0.28 & 0.03 & 0.54 \\
\hline Eigen values & 9.13 & 3.40 & 2.75 & 2.48 \\
\hline$\%$ of variance & 45.67 & 16.99 & 13.74 & 12.38 \\
\hline Cumulative $\%$ of variance & 45.67 & 62.66 & 76.4 & 88.78 \\
\hline
\end{tabular}

Factor loadings $>0.6$ are in italics

sediments (including iron oxide minerals) of varying sizes and deposit them in different parts of the lake bed.

Apart from the surface runoff due to the melting of snow/ice, wind plays a substantial role in transport of sediments in Antarctica. This is due to the higher velocities of the wind and an increased density of the cold air (Atkins and Dunbar 2009), the latter enhancing the drag force over the sediment particles. Laboratory studies have shown that transport of bed load by wind can be due to either traction (particle size $>2000 \mu \mathrm{m}$ ), saltation (particle size between 70 and 2000 $\mu \mathrm{m}$ ), or suspension (particle size $<70 \mu \mathrm{m}$ ) (Pye 1987; Atkins and Dunbar 2009). Moreover, particles less than $100 \mu \mathrm{m}$ in diameter tend to move in suspension (Zobeck and van Pelt 2005), or by the impacts of saltating particles on them (Újvári et al. 2016). The movement of a particle initiates when shear stresses generate lifting force larger than the particles' stabilizing force (Magar 2020). That is, the motion starts when threshold shear velocity $\left(U_{*}\right)$ is exceeded by the shear velocity $\left(U_{t}\right.$; Ellis and Sherman 2013). In temperate regions, the threshold velocities needed for the entrainment of fine sand $\left(150 \mu \mathrm{m}\right.$ ) vary between 5 and $7.5 \mathrm{~m} \mathrm{~s}^{-1}$ (McCauley et al. 1981; McGowan 1997). However, in parts of Antarctica, especially, the Southern McMurdo Sound and the McMurdo Dry Valleys, this threshold velocity is $\sim 5.5 \mathrm{~m} \mathrm{~s}^{-1}$ due to a combination of cold temperatures and denser air (Ayling and McGowan 2006; Atkins and Dunbar 2009). In the Schirmacher Oasis, the winter months are the windiest with an average wind speed of $9.26 \mathrm{~m} \mathrm{~s}^{-1}$ (Soni et al. 2017), whereas during the summer months, the wind speed varies between 6.17 and $7.20 \mathrm{~m} \mathrm{~s}^{-1}$ (Soni et al. 2017). These wind velocity values are based on a detailed climatology of meteorological measurements for the past 25 years (1990-2015) carried out at the Maitri Research Base in the Schirmacher Oasis (Soni et al. 2017). The magnetic grain sizes are extremely small, and in terms of the sediment particle size, the iron oxide crystals belong mainly to the clay $(<2 \mu \mathrm{m})$ and medium silt $(16-32$ $\mu \mathrm{m})$ fractions. However, MD grains of larger size may fall under the coarse silt $(32-63 \mu \mathrm{m})$ and sand $(>63 \mu \mathrm{m})$ fractions (Hatfield 2014). Hence, the relatively higher wind velocities experienced in Schirmacher Oasis are sufficient to entrain the magnetic minerals of SP, SSD, and MD grain sizes from the catchment or from distant regions and deposit them at different places as there is a dip in the threshold velocity. Besides, on a smaller scale, the sediments (including iron oxide minerals) can also be re-distributed by the movement of birds like skuaa. This was observed during the sample collection, when a skuaa was seen walking from one place to another within the lake basin in order to protect its nest which was attached to the lake basin. However, we express caution on this, and studies need to be made to assess the contribution of the avian community in the re-distribution of sediment particles (including iron oxide minerals) within the lake basin in the Antarctic environment. In summary, the iron oxide minerals are welldistributed across the Lake L-55 sedimentary basin, and they seem to be transported from nearby regions as well as distant places by both modes of transportation, i.e., melt water channels and winds. In terms of the sedimentary particle size, the littoral regions of the Lake L-55 should have coarser sediments. This is because the littoral areas act as regions of redistribution (combined effect of entrainment, erosion, and transport under improved hydrodynamic conditions) of sediment particles, and the profundal zones act as regions where the finer sediments are deposited. A close look at the magnetic properties suggests that the eastern section of the Lake L-55 receives a relatively higher proportion of coarse-grained particles when compared to the other parts of the lake basin. This is evident by the low values of the $\chi_{\mathrm{ARM}} / \mathrm{SIRM}$ ratio. A detailed particle size analysis supported by geochemical and petrographic studies should help in deciphering the provenance of the sediments in Lake L-55.

\section{Conclusions}

In this study, the environmental magnetic properties of iron oxide minerals present in the Lake L-55 sediments, a dried 

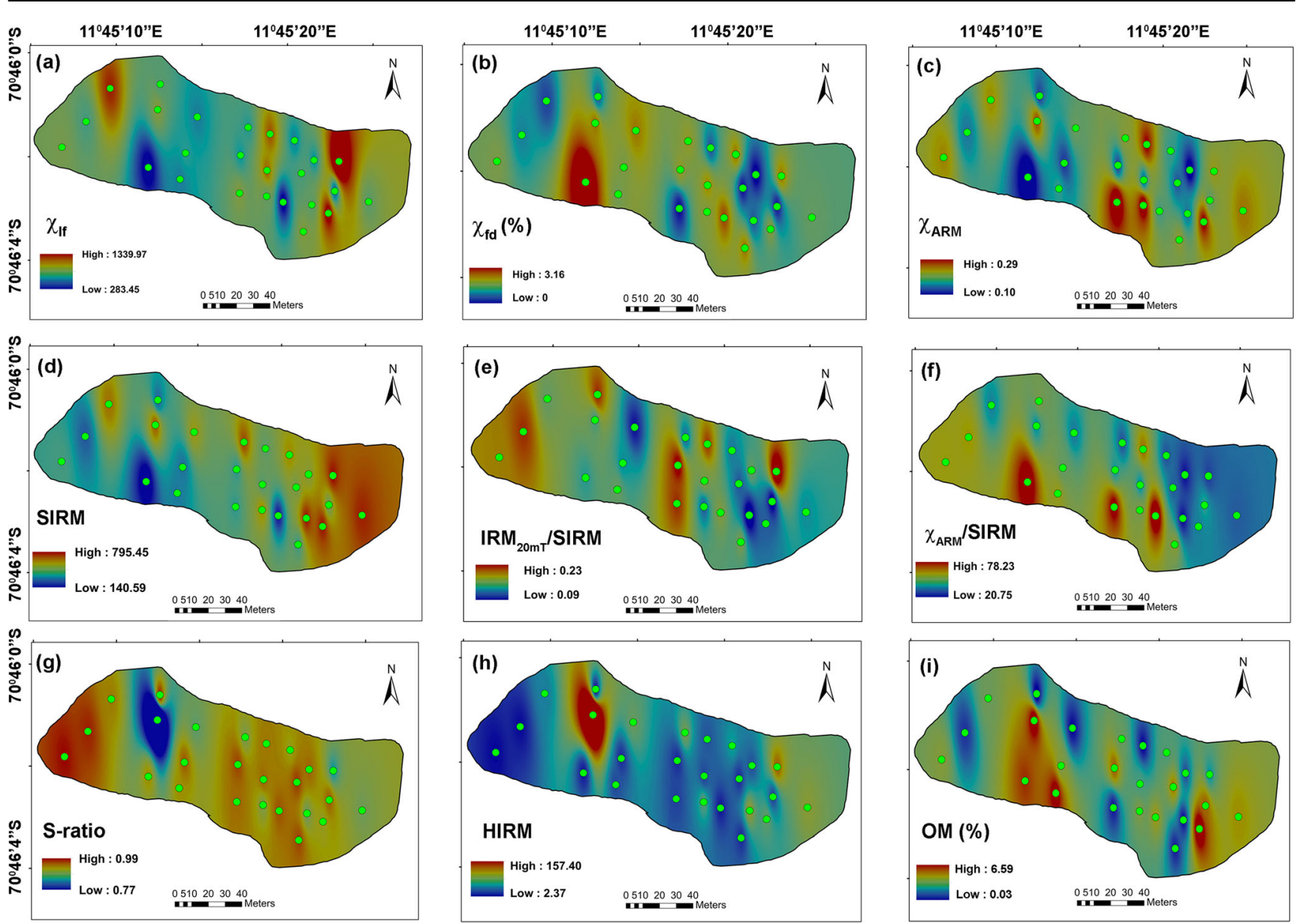

Fig. 7 Spatial distribution (using the inverse distance weighed (IDW) interpolation method) of the magnetic properties of iron oxide minerals and organic matter present in the surface sediments of Lake L-55

lake in Schirmacher Oasis, East Antarctica, were analyzed. The major findings are the following:

- The iron oxide minerals are mainly terrigenous. There is no overprinting of the magnetic signal by the formation of bacterial magnetite, anthropogenic magnetite, and authigenic greigite. The iron oxide minerals do not show any signs of dissolution.

- Organic matter content is low in the sediments and exhibits a negative relationship with the magnetic properties.

- High $\chi_{\mathrm{If}}$ and SIRM values indicate a high magnetic mineral concentration in the sediments, main contribution to which is by ferrimagnetic minerals (high $S$-ratio values) like titanomagnetite/magnetite. Their presence is further confirmed by SEM-EDS studies on magnetic extracts.

- The magnetic minerals in the sediments are of different grain sizes, and their contribution is in the order of MD > SSD $>$ SP as shown by the principal component analysis.

- The presence of pedogenic hematite is seen in the sediments which is probably due to the rapid oxidation of finegrained magnetite to maghemite and then to hematite. A strong positive correlation between $\chi_{\mathrm{ARM}}$ and HIRM suggests that the hematite crystals formed due to this process are mainly SSD-sized.

- The spatial distribution of iron oxide minerals shows that the eastern flank of the Lake L-55 sedimentary basin has a higher proportion of coarse-grained ferrimagnetic content.

- The sediments (including iron oxide minerals) are transported to the lake basin by a combination of processes, namely, melt water streams arising in the catchment due to the thawing of the snow and ice sheet, and the winds whose speed is greater than the threshold velocity needed to entrain the fine particles from the catchment region.

Supplementary Information The online version contains supplementary material available at https://doi.org/10.1007/s11368-020-02824-8.

Acknowledgments AKW thanks the Director, CSIR-NIO, Goa, and Dr Firoz Badesab, Scientist, CSIR-NIO, for kindly allowing access to their magnetic instrumental facility for measurements. MBS and RM are thankful to the Director, NCPOR for constant support and encouragement. We are thankful to the Antarctic Logistics Division, NCPOR, Mr. Jeeva, K., Leader and Station Commander, Maitri, and the members of the 38th and 39th Indian Scientific Expedition to Antarctica for their 
assistance during the field work. AKW thanks Dr Karina Lecomte for kindly sharing the magnetics data of lake sediments from the Antarctic Peninsula. AKW greatly appreciates the help rendered by Sahina Gazi and Akshaya Teli, National Centre for Polar and Ocean Research, Goa, in generating the SEM-EDS data. The authors thank Dr Philip N Owens (Editor-in-Chief), Dr Marcos A.E. Chaparro, Dr Simon Pulley (Submissions Editor), and an anonymous reviewer for their thoughtful comments that have significantly helped in improving the manuscript. This is NCPOR contribution no. J-74/2020-21.

Authors' contribution Anish Kumar Warrier: Conceptualization, investigation, original draft, funding acquisition, resources, and project administration.

Joju George Sebastian: Methodology, investigation, formal analysis, and visualization

K. Amrutha: Methodology, investigation, formal analysis, and visualization

Yamuna Sali, AS: Methodology, investigation, and formal analysis

Mahesh B S: Conceptualization, investigation, and writing - review and editing.

Rahul Mohan: Funding acquisition, resources, writing - review and editing, and project administration

Funding Open access funding provided by Manipal Academy of Higher Education, Manipal. The financial support for this work was provided by the ESSO-National Centre for Polar and Ocean Research, Ministry of Earth Sciences, Government of India, in the form of a research project (Sanction: NCPOR/2019/PACER-POP/ES-02 dated 05/07/2019) under the PACER Outreach Programme (POP) initiative.

Data availability Data will be made available if requested.

\section{Compliance with ethical standards}

Conflict of interest The authors declare that they have no conflict of interest.

\section{Code availability Nil}

Open Access This article is licensed under a Creative Commons Attribution 4.0 International License, which permits use, sharing, adaptation, distribution and reproduction in any medium or format, as long as you give appropriate credit to the original author(s) and the source, provide a link to the Creative Commons licence, and indicate if changes were made. The images or other third party material in this article are included in the article's Creative Commons licence, unless indicated otherwise in a credit line to the material. If material is not included in the article's Creative Commons licence and your intended use is not permitted by statutory regulation or exceeds the permitted use, you will need to obtain permission directly from the copyright holder. To view a copy of this licence, visit http://creativecommons.org/licenses/by/4.0/.

\section{References}

Anderson NJ, Rippey B (1988) Diagenesis of magnetic minerals in the recent sediments of a eutrophic lake. Limnol Oceanogr 33:14761492

Atkins CB, Dunbar GB (2009) Aeolian sediment flux from sea ice into southern McMurdo Sound, Antarctica. Glob Planet Ch 69:133-141

Avinash K, John Kurian P, Warrier AK, Shankar R, Vineesh TC, Ravindra R (2016) Sedimentary sources and processes in the eastern
Arabian Sea: insights from environmental magnetism, geochemistry and clay mineralogy. Geosci Front 7:253-264

Ayling BF, McGowan HA (2006) Niveo-eolian sediment deposits in coastal South Victoria Land, Antarctica: indicators of regional variability in weather and climate. Arct Antarct Alp Res 38(3):313-324

Aymerich IF, Oliva M, Giralt S, Martín Herrero J (2016) Detection of tephra layers in Antarctic sediment cores with hyperspectral imaging. PLoS One 11(1):e0146578. https://doi.org/10.1371/journal. pone. 0146578

Bose S, Sengupta S (2003) High temperature mylonitisation of quartzofeldspathic gneisses: example from the Schirmacher Hills, east Antarctica. Gondwana Res 6(4):805-816

Cao L, Appel E, Hu S, Yin G, Lin H, Rösler W (2015) Magnetic response to air pollution recorded by soil and dust-loaded leaves in a changing industrial environment. Atmos Environ 119:304-313

Chaparro MAE, Nuñez H, Lirio JM, Gogorza CSG, Sinito AM (2007) Magnetic screening and heavy metal pollution studies in soils from Marambio station, Antarctica. Antarct Sci 19(3):379-393

Chaparro MAE, Gargiulo JD, Irurzun MA et al (2014) El uso de parámetros magnéticos en estudios paleolimnológicos en Antártida. Latin Am J Sediment Basin Anal 21:77-96

Chaparro MAE, Chaparro M, Córdoba F et al (2017) Sedimentary analysis and magnetic properties of Lake Anónima, Vega Island. Antarct Sci 29(5):429-444

Chaparro MAE, Moralejo MP, Böhnel HN, Acebal SG (2020a) Iron oxide mineralogy in mollisols, aridisols and entisols from southwestern Pampean region (Argentina) by environmental magnetism approach. Catena 190:104534

Chaparro MAE, Chaparro MAE, Castañeda-Miranda AG, Marié Dé C, Gargiulo JD, Lavornia JM, Natal M, Böhnel HN (2020b) Fine air pollution particles trapped by street tree barks: in situ magnetic biomonitoring. Environ Pollut 266:115229. https://doi.org/10.1016/j. envpol.2020.115229

Chen T, Xie Q, Xu H, Chen J, Ji J, Lu H, Balsam W (2010) Characteristics and formation mechanism of pedogenic hematite in Quaternary Chinese loess and paleosols. Catena 81:217-225

Dankers PH (1978) Magnetic properties of dispersed natural iron oxides of known grain size, $\mathrm{PhD}$ thesis, University of Utrecht

Dearing JA (1999a) Holocene environmental change from magnetic proxies in lake sediments. In: Maher BA, Thompson R (eds) Quaternary climates, environments and magnetism. Cambridge University Press, Cambridge, pp 231-278

Dearing JA (1999b) Magnetic susceptibility. In: Walden J, Smith JP, Oldfield F (eds) Environmental magnetism - a practical guide. Technical Guide, no. 6. Quaternary Research Association, London, pp 35-62

Dearing JA, Bird PM, Dann RJL, Benjamin SF (1997) Secondary ferromagnetic minerals in Welsh soils: a comparison of mineral magnetic detection methods and implications for mineral formation. Geophys J Int 130:727-736

Dekkers MJ (2007) Magnetic proxy parameters. In: Gubbins D, HerreroBervera E (eds) Encyclopedia of geomagnetism and paleomagnetism. Springer, Amsterdam, pp 525-534

Dunlop DJ, Ozdemir O (2001) Rock magnetism - fundamentals and frontiers. Cambridge University Press, Cambridge, p 573

Ellis JT, Sherman DJ (2013) Fundamentals of aeolian sediment transport: wind-blown sand. Treat Geomorph 11:85-108

Evans ME, Heller F (2003) Environmental magnetism: principles and applications of enviromagnetics. Academic Press, San Diego, p 299

Farebrother W, Hesse PP, Chang H-C, Jones C (2017) Dry lake beds as sources of dust in Australia during the Late Quaternary: a volumetric approach based on lake bed and deflated dune volumes. Quat Sci Rev 161:81-98

Foster IDL, Oldfield F, Flower RJ, Keatings K (2008) Mineral magnetic signatures in a long core from Lake Qarun, Middle Egypt. J Paleolimnol 40:835-849 
Frontier S (1976) Study of the decrease of eigenvalues in principal component analysis: comparison with the broken stick model. J Exp Mar Biol Ecol 25:67-75

Guan H, Chen L, Luo M, Liu L, Mao S, Ge H, Zhang M, Fang J, Chen D (2019) Composition and origin of lipid biomarkers in the surface sediments from the southern Challenger Deep, Mariana Trench. Geosci Front 10:351-360

Hammer Ø, Harper DAT, Ryan PD (2001) PAST: paleontological statistics software package for education and data analysis. Palaeontol Electron 4(1):9

Harper DAT (1999) Numerical palaeobiology. Wiley, p 478

Hatfield RG (2014) Particle size-specific magnetic measurements as a tool for enhancing our understanding of the bulk magnetic properties of sediments. Minerals 4:758-787

Hendy C, Sadler A, Denton G, Hall B (2000) Proglacial lake-ice conveyors: a new mechanism for the deposition of drift in polar environments. Geogr Ann 82A:249-270

Hounslow M, Maher BA (1999) Laboratory procedures for quantitative extraction and analysis of magnetic minerals from sediments. In: Walden J, Smith JP, Oldfield F (eds) Environmental MagnetismA Practical Guide. Technical Guide, no. 6. Quaternary Research Association, London, pp 139-184

Huliselan EK, Bijaksana S, Srigutomo W, Kardena E (2010) Scanning electronic microscopy and magnetic characterization of iron oxides in solid waste landfill leachate. J Hazard Mater 179:701-708

Ingole BS, Parulekar AH (1993) Limnology of freshwater lakes at Schirmacher Oasis, East Antarctica. P Indian Natl Sci Acad B 59(6):589-600

Jolliffe IT (2002) Principal Component Analysis, 2nd edn. SpringerVerlag, New York, p 487

Khare N, Chaturvedi SK, Saraswat R, Srivastava R, Raina R, Wanganeo A (2008) Some morphometric characteristics of Priyadarshini water body at Schirmacher Oasis, central Dronning Maud Land, Antarctica with special reference to its bathymetry. Ind J Mar Sci 37(4):435-438

King JW, Banerjee SK, Marvin J, Õzdemir Õ (1982) A comparison of different magnetic methods for determining the relative grain size of magnetite in natural materials: some results from lake sediments. Earth Planet Sci Lett 59:404-419

Lal RP (2006) A short period climatology of Maitri: Schirmacher oasis, east Antarctica. Mausam 57:684-687

Lanci L, Delmonte B, Kent DV, Maggi V, Biscaye PE, Petit J-R (2012) Magnetization of polar ice: a measurement of terrestrial dust and extraterrestrial fallout. Quat Sci Rev 33:20-31

Laybourn-Parry J, Wadham J (2014) Antarctic lakes. Oxford University Press, ISBN 978-0-19-967050-5, p 215

Lecomte KL, Vignoni P, Córdoba FE, Chaparro MAE, Chaparro MAE, Kopalova K, Gargiulo JD, Lirio JM, Irurzun MA, Böhnel HN (2016) Hydrological systems from the Antarctic Peninsula under climate change: James Ross Archipelago as study case. Environ Earth Sci 75:623. https://doi.org/10.1007/s12665-016-5406-y

Li Y-X, Yu Z, Kodama KP, Moeller RE (2006) A 14,000-year environmental change history revealed by mineral magnetic data from White Lake, New Jersey, USA. Earth Planet Sci Lett 246:27-40

Li F, Ginoux P, Ramaswamy V (2010) Transport of Patagonian dust to Antarctica. J Geophys Res 115:D18217

Liu Q, Roberts AP, Torrent J, Horng C-S, Larrasoaña JC (2007) What do the HIRM and S-ratio really measure in environmental magnetism? Geochem Geophys Geosyst 8:Q09011. https://doi.org/10.1029/ 2007GC001717

Liu Q, Roberts AP, Larrasoaña JC, Banerjee SK, Guyodo Y, Tauxe L, Oldfield F (2012) Environmental magnetism: principles and applications. Rev Geophys 50:RG4002

Lu SG, Bai SQ (2006) Study on the correlation of magnetic properties and heavy metals content in urban soils of Hangzhou City, China. J Appl Geophys 60:1-12
Magar V (2020) Sediment transport and morphodynamics modelling for coasts and shallow environments. CRC Press, Taylor \& Francis Group, p 214

Magiera T, Jabłońska M, Strzyszcz Z, Rachwał M (2011) Morphological and mineralogical forms of technogenic magnetic particles in industrial dusts. Atmos Environ 45:4281-4290

Maher BA (1988) Magnetic properties of some synthetic submicron magnetites. Geophys J Int 94:83-96

Maher BA (2009) Rain and dust: magnetic records of climate, and pollution. Elements 5:229-234

Maher BA, Taylor RM (1988) Formation of ultrafine-grained magnetite in soils. Nature 336:368-370

Mahesh BS, Warrier AK, Mohan R, Tiwari M, Anila B, Chandran A, Asthana R, Ravindra R (2015) Response of Long Lake sediments to Antarctic climate: a perspective gained from sedimentary organic geochemistry and particle size analysis. Pol Sci 9:359-367

Mahesh BS, Warrier AK, Mohan R, Tiwari M, Roy R, Asthana R, Ravindra R (2017) Response of Sandy Lake in Schirmacher oasis, east Antarctica to the glacial-interglacial climate shift. J Paleolimnol 58:275-289

Mahesh BS, Warrier AK, Mohan R, Tiwari M (2019) Impact of Antarctic climate during the Late Quaternary: records from Zub Lake sedimentary archives from Schirmacher hills, east Antarctica. Palaeogeogr Palaeoclimatol Palaeoecol 514:398-406

McCauley JF, Breed CS, Grolier MJ, Mackinnon DJ (1981) The U.S. dust storm of February, 1977. In: Pewe TL (Ed) Desert Dust: Origin, Characteristics and Effects on Man: Geol Soc Amer Sp 186:123147

McGowan HA (1997) Meteorological controls on wind erosion during foéhn wind events in the eastern Southern Alps, New Zealand. Can J Earth Sci 34:1477-1485

Oldfield F (1991) Environmental magnetism - a personal perspective. Quat Sci Rev 10:73-85

Oldfield F (1994) Toward the discrimination of fine grained ferrimagnets by magnetic measurements in lake and nearshore marine sediments. J Geophys Res 99:9045-9050

Olsen RL, Chappell RW, Loftis JC (2012) Water quality sample collection, data treatment and results presentation for principal components analysis - literature review and Illinois River watershed case study. Water Res 46(9):3110-3122

Paasche O, Lovlie R, Dahl SO, Bakke J, Nesje A (2004) Bacterial magnetite in lake sediments: late glacial to Holocene climate and sedimentary changes in northern Norway. Earth Planet Sci Lett 223: 319-333

Peters C, Dekkers M (2003) Selected room temperature magnetic parameters as a function of mineralogy, concentration and grain size. Phys Chem Earth 28:659-667

Phartiyal B (2014) Holocene paleoclimatic variation in the Schirmacher oasis, east Antarctica: a mineral magnetic approach. Policy Sci 8: 357-369

Pulley S, Collins AL, Van der Waal B (2018) Variability in the mineral magnetic properties of soils and sediments within a single field in the Cape Fold mountains, South Africa: implications for sediment source tracing. Catena 163:172-183

Pye K (1987) Aeolian dust and dust deposits. Academic Press, London, p 334

Rao DR (2000) Metamorphic evolution of charnockites and felsic gneisses from the Schirmacher region, east Antarctica. Gondwana Res 3(1):79-89

Ravindra R (2001) Geomorphology of Schirmacher oasis, east Antarctica. Proceedings, symposium on snow, ice and glacier. Geol Sur Ind Spl Pub 53:379-390

Ravindra R (2020) Glacial sediments of Schirmacher oasis, east Antarctica and their characteristics. In: Goel PS, Ravindra R, Chattopadhyay $\mathrm{S}$ (eds) Climate change and the white world. Springer Nature, Switzerland, pp 31-57 
Roberts AP (1995) Magnetic properties of sedimentary greigite $\left(\mathrm{Fe}_{3} \mathrm{~S}_{4}\right)$. Earth Planet Sci Lett 134:227-236

Sagnotti L, Macri P, Camerlenghi A, Rebesco M (2001) Environmental magnetism of Antarctic late Pleistocene sediments and interhemispheric correlation of climatic events. Earth Planet Sci Lett 192:6580

Sandeep K, Warrier AK, Harshavardhana BG, Shankar R (2012) Rock magnetic investigations of surface and sub-surface soil samples from five lake catchments in tropical southern India. Int J Environ Res 6(1):1-18

Schumacher BA (2002) Methods for the determination of total organic carbon (TOC) in soils and sediments. Ecological Risk Assessment Support Center, Office of Research and Development, US Environmental Protection Agency

Shrivastava PK, Asthana R, Roy SK, Swain AK, Dharwadkar A (2012) Provenance and depositional environment of epi-shelf lake sediment from Schirmacher oasis, east Antarctica, vis-a-vis scanning electron microscopy of quartz grain, size distribution and chemical parameters. Policy Sci 6:165-182

Smith JA, Hodgson DA, Bentley MJ, Verleyen E, Leng MJ, Roberts SJ (2006) Limnology of two Antarctic epishelf lakes and their potential to record periods of ice shelf loss. J Paleolimnol 35:373-394

Snowball IF (1991) Magnetic hysteresis properties of greigite $\left(\mathrm{Fe}_{3} \mathrm{~S}_{4}\right)$ and a new occurrence in Holocene sediments from Swedish Lappland. Phys Earth Planet Inter 68:32-40

Snowball IF (1994) Bacterial magnetite and the magnetic properties of sediments in a Swedish lake. Earth Planet Sci Lett 126:129-142

Soni VK, Sateesh M, Das AK, Peshin SK (2017) Progress in meteorological studies around Indian stations in Antarctica. P Indian Natn Sci Acad 83:461-467

Srivastava AK, Khare N (2009) Granulometric analysis of glacial sediments, Schirmacher Oasis, East Antarctica. J Geol Soc India 73: $609-620$

Srivastava AK, Randive KR, Khare N (2013) Mineralogical and geochemical studies of glacial sediments from Schirmacher oasis, east Antarctica. Quat Int 292:205-216
Sudarningsih S, Bijaksana S, Ramdani R et al (2017) Variation in the concentration of magnetic minerals and heavy metals in suspended sediments from Citarum River and tributaries, West Java, Indonesia. Geosciences 7:66

Swain AK (2020) Glacier stress pattern as an indicator for climate change. In: Goel PS, Ravindra R, Chattopadhyay S (eds) Climate change and the white world. Springer Nature, Switzerland, pp 119-138

Újvári G, Kok JF, Varga G, Kovács J (2016) The physics of wind-blown loess: implications for grain size proxy interpretations in Quaternary paleoclimate studies. Earth-Sci Rev 154:247-278

Walden JF, Oldfield F, Smith J (1999) Environmental magnetism: a practical guide, No.6. Quaternary Research Association, London, 243 pp

Warrier AK, Mahesh BS, Mohan R, Shankar R, Asthana R, Ravindra R (2014) Glacial-interglacial climatic variations at the Schirmacher oasis, east Antarctica: the first report from environmental magnetism. Palaeogeogr Palaeoclimatol Palaeoecol 412:249-260

Warrier AK, Pednekar H, Mahesh BS, Mohan R, Gazi S (2016) Sediment grain size and surface textural observations of quartz grains in late quaternary lacustrine sediments from Schirmacher oasis, east Antarctica: paleoenvironmental significance. Pol Sci 10:89-100

Williamson D, Jelinowska A, Kissel C, Tucholka P, Gibert E, Gasse F, Massault M, Taieb M, Campo VE, Wieckowski K (1998) Mineralmagnetic proxies of erosion/oxidation cycles in tropical maar-lake sediments (Lake Tritrivakely, Madagascar): paleoenvironmental implications. Earth Planet Sci Lett 155:205-219

Xie S, Dearing JA, Bloemendal J (1999) A partial susceptibility approach to analysing the magnetic properties of environmental materials: a case study. Geophys J Int 138(3):851-856

Zobeck TM, van Pelt RS (2005) Erosion | wind-induced. Encycl Soils Environ:470-478

Publisher's note Springer Nature remains neutral with regard to jurisdictional claims in published maps and institutional affiliations. 